\title{
UPRAVLJANJE LJUDSKIM \\ POTENCIJALIMA KAO FUNKCIJA RUKOVOĐENJA \\ U POSLOVANJU KNJIŽNICE
}

\author{
HUMAN RESOURCES MANAGEMENT \\ AS A FUNCTION OF MANAGEMENT IN LIBRARY \\ OPERATIONS
}

\begin{abstract}
Antal Balog
Veleučilište s pravom javnosti „Baltazar“ Zaprešić

antal.balog@bak.hr
\end{abstract}

UDK / UDC: 005.96:021:025

Pregledni rad / Review paper

Primljeno / Received: 28. 2. 2021.

Prihvaćeno / Accepted: 10. 10. 2021.

\section{Sažetak}

Cilj ovog rada jest objasniti osnovne pojmove te izložiti glavne procese upravljanja ljudskim potencijalima kao jedne od funkcija rukovođenja. Nadalje, cilj mu je pridonijeti boljem poznavanju te rukovodne funkcije, njezinoj ulozi u ispunjavanju poslanja knjižnice te učinkovitom i uspješnom poslovanju knjižnice.

Pristup/metodologija/oblikovanje. Rasprava započinje razgraničavanjem i kratkom razradom osnovnih pojmova (radna snaga, kadrovi, ljudski resursi, ljudski potencijali, posao, radno mjesto, zanimanje i profesija knjižničara i informacijskih stručnjaka itd.) i sadržaja koji se odnose na ljudske potencijale. U nastavku rada koristi se desk research metoda te metoda analize uobičajenih i najčešćih procesa upravljanja ljudskim potencijalima, kao što su oblikovanje radnih mjesta i poslova, planiranje ljudskih potencijala, njihovo pridobivanje, odabir, uvođenje $u$ rad, motiviranje i nagrađivanje te obrazovanje i osposobljavanje.

Rezultati ovoga rada mogu pridonijeti boljem razumijevanju i učinkovitijem upravljanju ljudskim potencijalima u knjižnici.

Ograničenje se odnosi na istraživanje knjižnica samo u Republici Hrvatskoj.

Vjesnik bibliotekara Hrvatske 64, 2(2021), 233-263

ISSN 0507-1925 
Praktična primjena. Sadržaj ovoga članka može pomoći knjižničarima i njima srodnim profesijama u razumijevanju i primjeni upravljanja ljudskim potencijalima u rukovođenju knjižnicom.

Društveni značaj ovoga članka sadržan je u mogućnosti uspješnije primjene teorijskih spoznaja iz upravljanja ljudskim potencijalima u poslovanju knjižnica kao ustanova od posebnog društvenog interesa.

Originalnost i vrijednost ovog rada jest u povezivanju teorijskih razmatranja o upravljanju ljudskim potencijalima knjižnica s njihovom praktičnom primjenom u upravljanju i rukovođenju.

Ključne riječi: knjižnica, ljudski potencijali, ljudski resursi, rukovođenje.

\begin{abstract}
Goal. To explain the basic concepts and present the main processes of human resources management as one of the functions of library management. Furthermore, the goal is to contribute to a better knowledge of the managerial function and its role in fulfilling the mission of the library and running efficient and successful library operations.

Approach/methodology/design. The discussion begins with the delineation and brief elaboration of basic concepts (workforce, staff, human resources, human potentials, work, workplace, occupation and profession of librarians and information professionals and specialists, etc.) and clarification of the content related to human resources. In the next section of the paper, the desk research method and the method of analysis of common and most prevalent human resources management processes such as job and job design, human resource planning, attracting and acquiring new employees, selection for employment, motivation and rewarding, and education and training are used.
\end{abstract}

The results of this paper can contribute to a better understanding and more effective management of human resources in the library.

Limitations. The research is limited to libraries in the Republic of Croatia.

Practical implications. The content of this article can assist librarians and their related professions in understanding and applying human resources management in library management.

The social implications of this article are reflected in the possibility of a more successful application of theoretical knowledge of human resources management in the operation of libraries as institutions of special social interest.

The originality and value of this paper lie in the linking of theoretical considerations of library human resources management with their practical application in management and leadership.

Keywords: library, human potentials, human resources, management. 


\section{Uvod: kadrovsko popunjavanje (ili upravljanje ljudskim potenci- jalima) kao funkcija rukovođenja}

Korisno je podsjetiti čitatelje ovog časopisa da je za razliku od funkcije upravljanja, rukovođenje operativna i izvršna funkcija koja usmjerava poslovne aktivnosti i usklađuje raspoložive resurse poslovnog subjekta nastojeći provesti upravljačke odluke, odnosno ostvariti organizacijske ciljeve. U tom smislu glavni sadržaji funkcije rukovođenja jesu: (1) organiziranje i usklađivanje, (2) planiranje i odlučivanje, (3) kadrovsko popunjavanje - ili upravljanje ljudskim potencijalima, (4) vođenje i (5) kontroliranje. ${ }^{1}$ U nastavku teksta razmatrat ćemo rukovodeću funkciju kadrovskog popunjavanja, odnosno temeljne procese upravljanja ljudskim potencijalima.

\subsection{Razgraničavanje pojmova}

Nekim citatima autori jednostavno ne mogu odoljeti. Jedan od takvih odnosi se na ljudske resurse koji sažeto tvrdi kako je „kadrovska politika osnova svake politike". ${ }^{2}$ Posredna implikacija navedene tvrdnje jest da su ljudski resursi okosnica svake organizacije i potreban uvjet njezine učinkovitosti i uspješnosti funkcioniranja.

Bilo koja organizacija, gospodarska, državna, javna ili privatna, upravlja svojim resursima, odnosno sredstvima kojima nastoji ostvariti svoje poslanje, odnosno misiju, zatim strateške ciljeve te prema njima izvedene operativne zadatke. ${ }^{3}$ U organizacijskoj teoriji resursi se najčešće razvrstavaju u sljedeće skupine: (1) materijalne i financijske resurse (primjerice, sirovine, materijali, energija, oprema, nekretnine, sitni inventar, financijska sredstva itd.), (2) tehničke i organizacijske resurse (primjerice, tehnologija, tehnika, informacije i informacijski sustavi, sustavi organizacije, (3) nematerijalne resurse (primjerice, prava, patenti, licence, know-how itd.), (4) ljudske resurse (zaposlenici, volonteri, osobe na stručnom osposobljavanju bez zasnivanja radnog odnosa, vanjski suradnici itd.) ili, koristeći stariji termin, kadrovske resurse. ${ }^{4}$

\footnotetext{
1 Upravljanje je proslovni proces kojim osnivač ili osnivači utvrđuju osnovne determinante organizacije i funkcioniranja knjižnice, primjerice viziju, misiju, glavne ciljeve, opću organizacijsku strukturu, poslovne politike, strategije itd. Usp. Balog, A. Prema teorijskim ishodištima i primjeni modela rukovođenja. // Vjesnik bibliotekara Hrvatske 62, 2(2019), str. 67. DOI: https://doi. org/10.30754/vbh.62.2.761.

2 Izreka se pripisuje Josifu Visarionoviču Staljinu. Usp. Puhovski, Ž. Prednost demokracije pred znanošću. // Ideje.hr [citirano: 2020-10-30]. Dostupno na http://ideje.hr/prednost-demokracije-pred-znanoscu.

3 Usp. Ćupurdija, M.; B. Moslavac; A. Balog. Upravljanje ljudskim potencijalima i radni odnosi. Rijeka: Libertin naklada, 2019. Str. 125.

4 Usp. Villa, A. Organizacija in organiziranje. Kranj: Moderna organizacija, 1994. Str. 12.
} 
Ljudski su resursi najznačajniji resurs svake organizacije, pa tako i knjižnica. Bez njih nije moguće pokrenuti, organizirati i održavati funkcioniranje bilo koje organizacije. No taj pojam nije potpuno i uvijek prihvatljiv, s obzirom na to da se ljudi korištenjem tog termina izjednačavaju s ostalim organizacijskim resursima. Termin ljudski potencijali prikladniji je jer implicira poštivanje dostojanstva ljudske osobe i ukazuje na ključnu razliku ljudskog rada u odnosu na ostale organizacijske resurse. Ljudi imaju, za razliku od drugih resursa, potencijal rasta i razvoja, prilagođavanja okolnostima, mogućnost međusobnog obogaćivanja te stvaranje organizacijske sinergije.

Nadalje, ljudi u organizaciji u kojoj rade svoje ukupne sposobnosti malo kada ostvaruju odmah i u cijelosti, već samo djelomice. Sve neostvarene sposobnosti, kompetencije i znanja koja mogu steći, motivaciju koju trebaju razviti, kreativnost koja se može ostvariti itd., predstavljaju potencijale koji se tek trebaju realizirati. Prema tome, za ljudske potencijale možemo reći da sadrže dvije komponente. Prva se odnosi na postojeća znanja, kvalifikacije, sposobnosti, osobine ličnosti, motivaciju, kreativnost itd., a druga na sva buduća, odnosno potencijalna i još neostvarena znanja, kvalifikacije, sposobnosti itd. ${ }^{5}$

U stručnoj literaturi mogu se pronaći različiti pojmovi koji se odnose na radnu snagu, kadrove, ljudske resurse i ljudske potencijale. ${ }^{6}$ Radna snaga je ukupnost čovjekovih fizičkih i duhovnih sposobnosti koje se mogu koristiti za proizvodnju uporabnih vrijednosti bilo koje vrste. Ona također označava sve osoblje zaposleno u nekom poslovnom subjektu. ${ }^{7}$ Pojam kadra postupno zastarijeva, ali se još uvijek koristi u poslovnoj terminologiji. U početku svoje uporabe označavao je osobe koje obavljaju ili bi mogle obavljati neke značajne ili vodeće funkcije u organizaciji, primjerice organizacijski, rukovodeći, stručni i drugi kadar. Tijekom vremena uporaba se tog pojma proširila na sve osobe koje su zaposlene, promatrajući ih kao sredstvo ostvarivanja poslovnih ciljeva i kao organizacijski trošak.

Pojam ljudskih resursa postupno je zamijenio pojam kadrova te ima sličan sadržaj kao i pojam ljudskih potencijala, ali nema ugrađenu razvojnu, odnosno dinamičku dimenziju. Ljudski resursi imaju statičku dimenziju, predstavljaju sredstvo ili vrijednost koja je zadana i koju organizacija može koristiti. Za razliku od pojma ljudskih resursa, ljudski potencijali nagovještavaju mogućnost da se ljudski resursi mogu mijenjati, povećavati, usavršavati, dodatno oblikovati ili preoblikovati. Funkcioniranje organizacije može aktivirati one potencijale uposlenika

\footnotetext{
5 Usp. Ćupurdija, M.; B. Moslavac; A. Balog. Nav. dj., str. 126.

6 Osim navedenih, u poslovanju se koriste, između ostalih i sljedeći termini sa sličnim, ali ipak različitim značenjima: radnici, djelatnici, uposlenici, zaposlenici, službenici, činovnici, namještenici, osoblje, volonteri itd.

7 Radna snaga. // Hrvatska enciklopedija. Mrežno izd. Zagreb: Leksikografski zavod Miroslav Krleža, 1999. [citirano: 2020-10-30]. Dostupno na http://www.enciklopedija.hr/natuknica. aspx?id=51522.
} 
koji su bili skriveni, neaktivirani i neiskorišteni. Prema tome, pojam ljudski potencijali ukazuje na poslovnu filozofiju organizacije koja ljude promatra kao osnovni razvojni čimbenik te potencijalnu konkurentnu prednost.

$\mathrm{Na}$ temelju navedenog, ljudski potencijali mogu se definirati kao „ukupna znanja, vještine, sposobnosti, kreativne mogućnosti, motivacija i odanost kojom raspolaže neka organizacija (ili društvo). To je ukupna intelektualna i psihička energija koju organizacija može angažirati na ostvarivanju ciljeva i razvoja poslovanja." ${ }^{\text {8 }}$

\subsection{Knjižničarke i knjižničari - tko su ta bića?}

U knjižnicama su knjižničari glavni, premda ne i jedini nositelji poslovanja knjižnice. Otuda i pitanje: knjižničari i knjižničarke - tko su ta bića? Aparac-Gazivoda ih sažeto opisuje kao „stručnjake koji posreduju u komunikacijskom procesu što teče između autora, odnosno njegova djela i korisnika knjižničnih službi i usluga ${ }^{\text {" }}$ Slična definicija knjižničara navedena je u IFLA-inim smjernicama za narodne knjižnice: „Knjižničar je djelatni posrednik između korisnika i građe.“10

Knjižničari doista jesu posrednici između autora i korisnika i ta im je uloga dominantna i najuočljivija. Međutim, oni obavljaju niz drugih funkcija koje prethode, nadovezuju se i proširuju njihovu primarnu posredničku ulogu. Primjerice nabavljaju, čuvaju, zaštićuju i održavaju knjižnični fond, klasificiraju ga i katalogiziraju, izvješćuju, razmjenjuju, obavljaju poslove revizije, organiziraju, upravljaju i rukovode knjižničnim ustanovama, pripremaju stručne i znanstvene radove u području knjižničarstva i knjižničarstvu srodnih disciplina i stručno se usavršavaju itd. Prema tome, u vrlo širokom smislu knjižničari sudjeluju, izravno ili posredno, u planiranju, oblikovanju i vođenju specifičnih javnih politika koje se odnose na knjižničarstvo i njima srodne djelatnosti, a koje su povezane i umrežene s područjima obrazovanja, znanosti, kulture, gospodarstva, politike, zabave itd. ${ }^{11}$

Na profiliranje knjižničnog zanimanja kao samostalne profesije tijekom proteklih povijesnih razdoblja utjecali su brojni čimbenici. Od endogenih čimbenika možemo navesti dva koja smatramo najznačajnijima: (1) postupni razvoj osnov-

\footnotetext{
8 Bahtijarević Šiber, F. Management ljudskih potencijala. Zagreb: Golden marketing, 1999. Str. 16.

9 Aparac-Gazivoda, T. Teorijske osnove knjižnične znanosti. Zagreb: Filozofski fakultet, Zavod za informacijske studije, 1993. Str. 171.

10 IFLA-ine smjernice za narodne knjižnice. / uredili C. Koontz i B. Gubbin. Zagreb: Hrvatsko knjižničarsko društvo, 2011. Str. 79.

11 Definicija knjižnične profesije u užem smislu može se pronaći kod Rubina, koji navodi tri uloge knjižničara i informatologa: obrazovnu, informacijsku i društveno-kulturnu. Navedena klasifikacija knjižničarskih uloga mogla bi se smatrati dostatnom sa stajališta korisnika. Ona, međutim, zanemaruje brojne druge uloge koje knjižničari preuzimaju. Usp. Rubin, R. E. Foundation of library and information science. London: Facet Publishing 2016. Str. 290-292.
} 
nih i pratećih funkcija knjižničarstva, odnosno razvoj i širenje glavnih poslova knjižničara te (2) prevladavajuće paradigme u knjižničarstvu, kako ih nazivaju Aparac-Jelušić i Faletar Tanacković, koje su izrastale iz osnovnih funkcija knjižničarstva. ${ }^{12}$

Tablica 1. Razvoj knjižničnih funkcija s prevladavajućim paradigmama u knjižničarstva ${ }^{13}$

\begin{tabular}{|l|l|l|}
\hline Razdoblje & Osnovne funkcije knjižničarstva & $\begin{array}{l}\text { Prevladavajuće paradigme u } \\
\text { knjižničarstvu }\end{array}$ \\
\hline Stari vijek & $\begin{array}{l}\text { Prikupljanje, čuvanje, bilježenje, } \\
\text { prepisivanje, korištenje za } \\
\text { povlaštene. }\end{array}$ & $\begin{array}{l}\text { Kulturološka, memorijska, } \\
\text { obrazovna za povlaštene. }\end{array}$ \\
\hline Srednji vijek & $\begin{array}{l}\text { Prikupljanje, čuvanje, bilježenje, } \\
\text { prepisivanje, korištenje za } \\
\text { povlaštene. }\end{array}$ & $\begin{array}{l}\text { Kulturološka, funkcionalna, } \\
\text { bibliofilska, obrazovna za } \\
\text { povlaštene. }\end{array}$ \\
\hline $\begin{array}{l}\text { Od 15. do } \\
\text { 17. stoljeća }\end{array}$ & $\begin{array}{l}\text { Prikupljanje, čuvanje, bilježenje, } \\
\text { prepisivanje, organizacija za } \\
\text { (javno) korištenje. }\end{array}$ & $\begin{array}{l}\text { Kulturološka, memorijska, } \\
\text { reprezentativna, obrazovna, } \\
\text { dostupna svima koji čitaju. }\end{array}$ \\
\hline $\begin{array}{l}\text { Od 18. do } \\
\text { 20. stoljeća }\end{array}$ & $\begin{array}{l}\text { Prikupljanje, čuvanje, organizacija } \\
\text { za javno korištenje, obrada } \\
\text { (formalna i sadržajna), organizirane } \\
\text { usluge za korisnike. }\end{array}$ & $\begin{array}{l}\text { Kulturološka, memorijska, } \\
\text { reprezentativna, obrazovna, } \\
\text { dostupna svima koji čitaju. }\end{array}$ \\
\hline $\begin{array}{l}\text { Do 60-ih } \\
\text { godina 20. } \\
\text { stoljeća }\end{array}$ & $\begin{array}{l}\text { Prikupljanje, čuvanje, organizacija } \\
\text { za javno korištenje, obrada } \\
\text { (formalna i sadržajna), organizirane } \\
\text { usluge za korisnike, uporaba } \\
\text { mehaničkih pomagala. }\end{array}$ & $\begin{array}{l}\text { Kulturološka, memorijska, } \\
\text { reprezentativna, obrazovna, } \\
\text { dostupna svima koji čitaju, } \\
\text { privlačna rastućem broju } \\
\text { osoba, usmjerena na prijenos } \\
\text { i posredovanje informacija i } \\
\text { zabilježenog znanja. }\end{array}$ \\
\hline $\begin{array}{l}\text { Od 60-ih } \\
\text { godina 20. } \\
\text { stoljeća }\end{array}$ & $\begin{array}{l}\text { Prikupljanje, (selektivno) čuvanje, } \\
\text { ograda (formalna i sadržajna) uz } \\
\text { podršku računala, organizirane } \\
\text { usluge za korisnike, organizacija } \\
\text { zaff-line i online pretraživanja, } \\
\text { vrednovanje informacija, } \\
\text { posredovanje. }\end{array}$ & $\begin{array}{l}\text { Kulturološka, memorijska, } \\
\text { reprezentativna, obrazovna, } \\
\text { dostupna svima, privlačna } \\
\text { rastućem broju osoba, } \\
\text { usmjerena na prijenos i } \\
\text { posredovanje informacija i } \\
\text { zabilježenog znanja, pouzdana. }\end{array}$ \\
\hline
\end{tabular}

12 Aparac-Jelušić, T.; S. Faletar Tanacković. Knjižnična arhitektura: Prostor, kultura, identitet. Zagreb: Ljevak, 2020. Str. 53.

13 Isto, str. 54. 


\begin{tabular}{|l|l|l|}
\hline Razdoblje & Osnovne funkcije knjižničarstva & $\begin{array}{l}\text { Prevladavajuće paradigme u } \\
\text { knjižničarstvu }\end{array}$ \\
\hline $\begin{array}{l}\text { Prijelaz } \\
\text { tisućljeća }\end{array}$ & $\begin{array}{l}\text { Prikupljanje, (selektivno) čuvanje, } \\
\text { obavljanje stručnih poslova uz } \\
\text { pomoć računala novijih generacija, } \\
\text { organizacija za korištenje uz pomoć } \\
\text { računala i interneta, vrednovanje } \\
\text { velikih količina podataka, } \\
\text { posredovanje, primjena robotike } \\
\text { i umjetne inteligencije, primjena } \\
\text { marketinških metoda. }\end{array}$ & $\begin{array}{l}\text { Kulturološka, memorijska, } \\
\text { reprezentativna, obrazovna, } \\
\text { dostupna svima, privlačna, } \\
\text { ugodna, posrednička, } \\
\text { pouzdana, stvaralačka, } \\
\text { poticajna, zabavna, kritička, } \\
\text { demokratska, komunikacijsko } \\
\text { središte, središte zajednice. }\end{array}$ \\
\hline
\end{tabular}

Povijesni razvoj temeljnih funkcija knjižničarstva i njima pridruženih prevladavajućih knjižničnih paradigmi opisanih u prethodnoj tablici (tablica 1) postupno su oblikovale profile suvremenih knjižničnih zanimanja. Tijekom tog relativno dugog procesa, odigravale su se odgovarajuće prilagodbe metoda upravljanja ljudskim potencijalima u knjižnicama koje su preuzimane iz drugih djelatnosti. Utjecaji suvremenih knjižničnih funkcija i prevladavajuće paradigme u knjižničarstvu, unutarnjih i vanjskih čimbenika na oblikovanje obrazovnih profila knjižničnih djelatnika i drugih informacijskih stručnjaka te na metode i prakse upravljanja ljudskim potencijalima prikazuje slika 1.

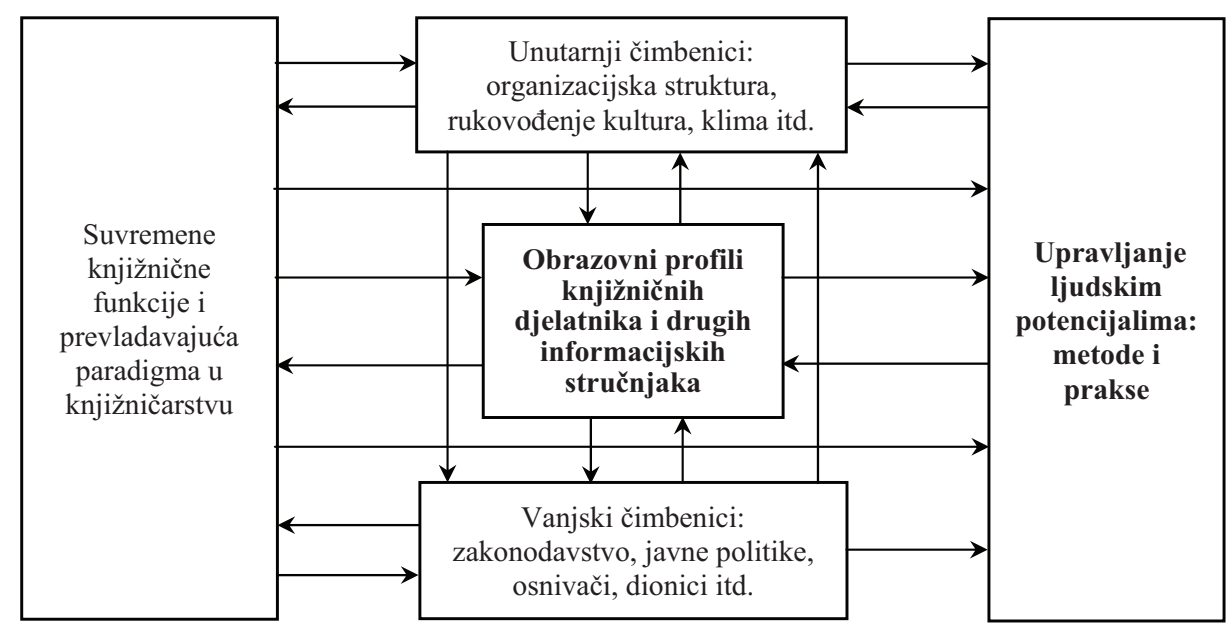

Slika 1. Međusobni utjecaji knjižničnih funkcija te vanjskih i unutarnjih čimbenika na oblikovanje obrazovnih profila knjižničnih djelatnika te na metode i prakse upravljanja ljudskim potencijalima 
Pojedini utjecaji prikazani na slici 1 nisu međusobno istovjetni, već se razlikuju prema vrsti, smjeru, intenzitetu i trajanju. Njihove odnose i dinamiku bilo bi korisno detaljnije istražiti kako bi se o tome stekla jasnija slika koja bi bila korisna u procesima organiziranja i rukovođenja.

Razmotrimo u nastavku zanimanje i profesiju knjižničara. Prema Hrvatskoj enciklopediji ,profesija je zanimanje koje ima, više ili manje specificiran, monopol nad nekim kompleksnim dijelom znanja i praktičnih vještina za koje je potrebno dugotrajno školovanje, tzv. visoko obrazovanje, te tako postaje prepoznatljivo u društvu“ “. ${ }^{14} \mathrm{Da}$ bi se neko zanimanje moglo smatrati profesijom ili paraprofesijom, potrebna su četiri uvjeta: (1) zakonska regulacija određenog zanimanja, (2) završeno odgovarajuće formalno obrazovanje, (3) položen stručni ispit kojim se dobiva odgovarajuća dozvola za rad i (4) postojanje profesionalnih asocijacija odnosno strukovnih organizacija (udruga, komora i slično) koje svojim djelovanjem zastupaju i štite profesionalne, stručne, radne i druge interese svojih članova te svojim dokumentima dodatno reguliraju poštivanje stručnih i etičkih normi profesije (primjerice etički i strukovni kodeksi, pravilnici, upute, nadzor rada, stručna usavršavanja, sudovi časti, časopisi i druge stručne publikacije, itd.). Kako zanimanje knjižničara ispunjava sve navedene kriterije, može se zaključiti da ono jest profesija u punom smislu. ${ }^{15}$

Prema Zakonu o reguliranim profesijama i priznavanju inozemnih stručnih kvalifikacija $^{16}$ i Popisu reguliranih profesija u Republici Hrvatskoj, ${ }^{17}$ profesija knjižničara vodi se kao regulirana. Regulirane profesije iz područja rada knjižnica, prema tim normativnim dokumentima jesu: knjižničarski savjetnik, viši knjižničar, diplomirani knjižničar, knjižničar, pomoćni knjižničar. Člancima 3., 4. i 5. Pravilnika o uvjetima i načinu stjecanja stručnih zvanja u knjižničnoj struci uz

14 Profesija. // Hrvatska enciklopedija. Mrežno izd. Zagreb: Leksikografski zavod Miroslav Krleža, 2021. [citirano: 2020-10-30]. Dostupno na http://www.enciklopedija.hr/Natuknica. aspx? ID $=50537$.

15 Machala u svojim istraživanjima razmatra povezanost kompetencijskog pristupa knjižničarskom zanimanju i oblikovanja knjižnične profesije. Usp. Machala, D. Knjižničarske kompetencije: Pogled na razvoj profesije. Zagreb: Hrvatska sveučilišna naklada, 2015.; ALA-ine kompetencije jezgre knjižničarstva. // Cjeloživotno učenje knjižničara: Ishodi učenja i fleksibilnost. / uredile A. Horvat i D. Machala. Zagreb: Nacionalna i sveučilišna knjižnica, 2009. Str. 177-180. [citirano: 2021-02-21]. Dostupno na: https://www.nsk.hr/cuk/cuk.pdf.;

16 Zakon o reguliranim profesijama i priznavanju inozemnih stručnih kvalifikacija: Narodne novine 82/15, 70/19, 47/20, na snazi od 25. 4. 2020. // Zakon.hr. [citirano: 2020-10-30]. Dostupno na: https://www.zakon.hr/z/499/Zakon-o-reguliranim-profesijama-i-priznavanju-inozemnih-stru\%C4\%8Dnih-kvalifikacija.

17 Popis reguliranih profesija u Republici Hrvatskoj. // Agencija za znanost i visoko obrazovanje. [citirano: 2020-10-30]. Dostupno na: https://www.azvo.hr/images/stories/enic/Popis_reguliranih_profesija_u_Republici_Hrvatskoj_3.1.2019.pdf. 
propisanu nadležnost Ministarstva kulture navode se i potanko opisuju stručna zvanja, uvjeti i načini za njihovo stjecanje. ${ }^{18}$

Nadalje, Nacionalna klasifikacija zanimanja 2010. - NKZ 10 navodi sljedeća knjižničarska zanimanja:

Tablica 2. Struktura nacionalne klasifikacije zanimanja (izvod) ${ }^{19}$

\begin{tabular}{|l|l|l|l|l|}
\hline Rod & Vrsta & Podvrsta & Skupina & \multicolumn{1}{c|}{ Naziv } \\
\hline 2 & & & & $\begin{array}{l}\text { Znanstvenici/znanstvenice, inženjeri/inžen- } \\
\text { jerke i stručnjaci/stručnjakinje. }\end{array}$ \\
\hline & & 262 & & $\begin{array}{l}\text { Knjižničari/knjižničarke, arhivisti/arhivistice i } \\
\text { stručno muzejsko osoblje. }\end{array}$ \\
\hline 3 & & & 2622 & $\begin{array}{l}\text { Knjižničari/knjižničarke i informacijski } \\
\text { stručnjaci/informacijske stručnjakinje. }\end{array}$ \\
\hline 4 & & & $\begin{array}{l}\text { Tehničari/tehničarke i stručni suradnici/stručne } \\
\text { suradnice. }\end{array}$ \\
\hline & & 3433 & $\begin{array}{l}\text { Galerijski i muzejski tehničari i knjižničari/ } \\
\text { galerijske i muzejske tehničarke i knjižničarke. }\end{array}$ \\
\hline
\end{tabular}

Međunarodna federacija knjižničnih udruga i institucija (IFLA) u svojim smjernicama za narodne knjižnice kategorizira osoblje knjižnica prema kriteriju stručnosti i školovanju razvrstavajući ga u sljedeće skupine: (1) školovani knjižničari, (2) pomoćno knjižnično osoblje, (3) stručno neknjižnično osoblje, (4) pomoćno neknjižnično osoblje i (5) pomoćno osoblje. ${ }^{20}$

Osim što se djelatnost knjižničarstva i rad knjižničara može promatrati u užem i širem smislu (u odnosu na uža ili šira društvena područja preko kojih se prostire), ono se može promatrati i prema dubini potrebe i obrade informacija. Društvo specijalnih knjižnica iz Sjedinjenih Američkih Država (Special Libraries Association - SLA), u svom dokumentu iz 2003. godine knjižničare opisuje kao stručnjake iz

\footnotetext{
18 Pravilnik o uvjetima i načinu stjecanja stručnih zvanja u knjižničarskoj struci. // Narodne novine 107/2021. [citirano: 2021-010-02]. Dostupno na https://narodne-novine.nn.hr/clanci/sluzbeni/2021_10_107_1886.html.

19 Usp. Nacionalna klasifikacija zanimanja 2010. - NKZ 10. // Narodne novine 147, 3736(2010). [citirano: 2021-02-21]. Dostupno na: https://narodne-novine.nn.hr/clanci/sluzbeni/2010_12_147_3736.html.

${ }^{20}$ IFLA-ine smjernice. Nav. dj., str. 80.
} 
kojih su se razvili ili evoluirali drugi informacijski stručnjaci kao što su ,upravljači znanjem (engl. knowledge managers), voditelji informacijskih odjela (engl. chief information officers), osobe koje razvijaju službe i usluge na mreži (engl. web developers), informacijske posrednike i savjetnike“. ${ }^{21}$

\section{Poslovni procesi upravljanja ljudskim potencijalima}

Upravljanje ljudskim potencijalima smatra se složenom aktivnošću u bilo kojem organizacijskom entitetu. Ta složenost može se pripisati, između ostalog, njezinoj izraženoj interdisciplinarnosti, odnosno povezanosti s antropologijom, psihologijom, sociologijom, socijalnom pedagogijom, industrijskom psihologijom, pedagogijom, odnosno andragogijom, s kulturologijom, komunikologijom i drugim znanostima.

Upravljanje ljudskim potencijalima objedinjuje nekoliko poslovnih procesa kojima poslovni subjekt nastoji osigurati optimalni broj i strukturu uposlenika. Tako S. Marušić navodi osamnaest procesa upravljanja ljudskim potencijalima, ${ }^{22}$ Bahtijarević-Šiber navodi četiri, ${ }^{23}$ Vodič kroz politike i procedure za upravljanje ljudskim potencijalima navodi ih osam ${ }^{24}$ itd.

U nastavku teksta razmotrit ćemo sljedeće procese upravljanja ljudskim potencijalima: (1) oblikovanje radnih mjesta i poslova, (2) planiranje ljudskih potencijala, (3) njihovo pridobivanje, odabir i uvođenje u rad, (4) motiviranje i nagrađivanje, (5) obrazovanje i osposobljavanje. Ostale procese upravljanja ljudskim

${ }^{21}$ Kompetencije informacijskih stručnjaka 21. stoljeća. // Cjeloživotno učenje knjižničara: Ishodi učenja i fleksibilnost. / uredile A. Horvat i D. Machala. Zagreb: Nacionalna i sveučilišna knjižnica u Zagrebu, 2009. Str. 171. [citirano: 2021-02-21]. Dostupno na: https://www.nsk.hr/cuk/cuk.pdf.

${ }^{22}$ Marušić navodi sljedeće poslovne procese upravljanja ljudskim potencijalima: (1) kadrovska politika, (2) analiza radnih mjesta, (3) planiranje, (4) pridobivanje (5) selekcija, (6) uvođenje u posao, (7) razvoj karijere, (8) izobrazba, (9) napredovanje, (10) konzultacije, (11) motivacija za rad, (12) kreativne tehnike, (13) ocjenjivanje uspješnosti, (14) nagrađivanje, (15) otkrivanje potencijalnih managera, (16) administracija, (17) informatika, komunikacije, (18) kontroling izvršenja. Usp. Marušić, S. Upravljanje ljudskim potencijalima. Zagreb: ADECO, 2001. Str. 92.

${ }^{23}$ Bahtijarević-Šiber navodi sljedeće poslovne procese upravljanja ljudskim potencijalima: (1) predviđanje potreba, (2) pribavljanje i selekcija, (3) motiviranje i nagrađivanje, (4) obrazovanje i razvoj. Usp. Bahtijarević-Šiber, F. Nav. dj., str. 120.

${ }^{24}$ Vodič kroz politike i procedure za upravljanje ljudskim potencijalima navodi sljedeće procese upravljanja ljudskim potencijalima: (1) zapošljavanje i odabir kadrova, (2) uvođenje u posao, (3) osposobljavanje i usavršavanje u svrhu profesionalnog razvoja i/ili napredovanja, (4) upravljanje učinkom, (5) ocjenjivanje zaposlenika, (5) upravljanje nagrađivanjem, (6) radni odnosi i odnosi sa zaposlenicima, (7) prekid radnog odnosa. Usp. Vodič kroz politike i procedure za upravljanje ljudskim potencijalima. Zagreb: Agencija za strukovno obrazovanje i obrazovanje odraslih. [citirano: 2021-02-21]. Dostupno na: https://www.asoo.hr/UserDocsImages/projekti/kapaciteti/Vodic\%20 kroz $\% 20$ politike $\% 20 \mathrm{i} \% 20$ procedure $\% 20 \mathrm{za} \% 20$ upravljanje $\% 20 \mathrm{LJP} . p d f$ 
potencijalima, kao što su rad volontera, ${ }^{25}$ upravljanje učinkom, ocjenjivanje, zapošljavanje i prekid radnog odnosa te neka problematična područja, kao što su stres i upravljanje stresom, konflikti, fluktuacija i apsentizam itd., ovim radom neće moći biti obuhvaćena. Prikaz funkcija upravljanja, rukovođenja i procesa upravljanja ljudskim potencijalima u knjižnici nalazi se na slici 2.

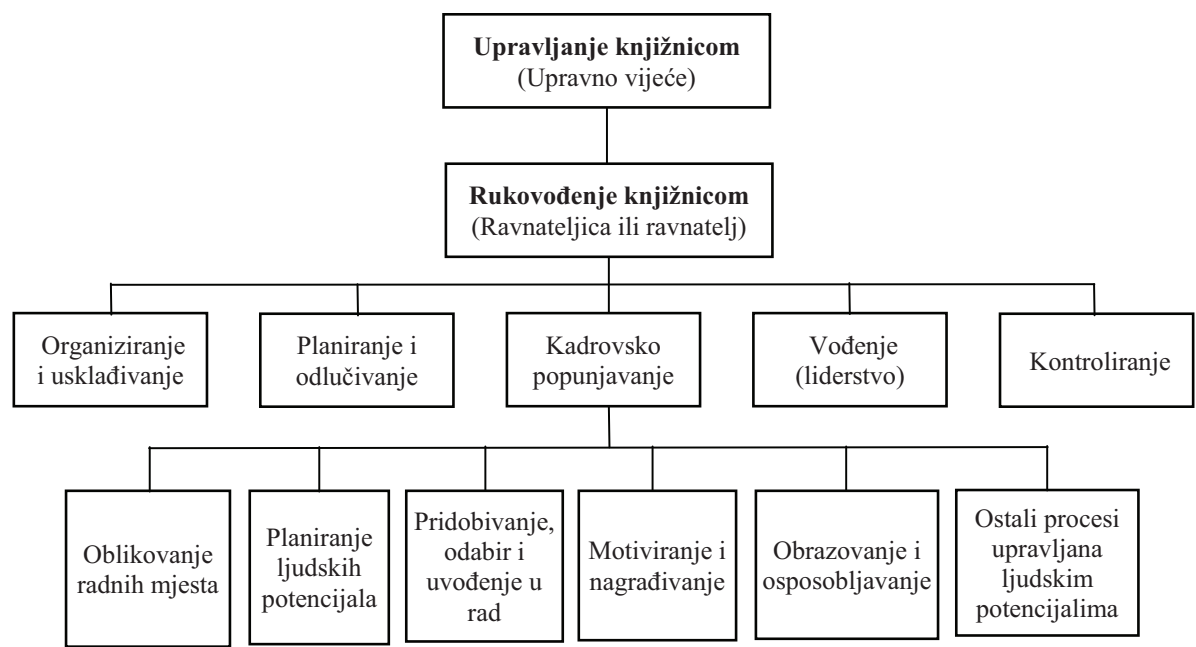

Slika 2. Odnos funkcija upravljanja, rukovođenja i procesa upravljanja ljudskim potencijalima

U nastavku teksta razmotrimo svaki od navedenih procesa upravljanja ljudskim potencijalima.

\subsection{Oblikovanje radnih mjesta i poslova u knjižnici}

Pojmovi koji se odnose na posao i radno mjesto nisu identični premda ih se ponekad poistovjećuje. Posao je radna aktivnost jedne ili više osoba u izvršavanju određene radne zadaće, dužnosti ili obveze. Primjerice, posao knjižničara je rad u knjižnici. Radno mjesto je, za razliku od posla, organizacijski pojam kojim je određen najmanji dio organizacijske strukture. Ono sadrži sljedeće elemente: radnika ili radnicu, poslove i zadaće koje radnik ili radnica obavljaju, sredstva i predmete rada, prostor za rad i odgovarajuće radne uvjete, ovlasti i odgovornosti odnosno položaj u organizacijskom ustroju. ${ }^{26} \mathrm{Na}$ radnom mjestu radnik može obavljati jedan

${ }^{25}$ Usp. Balog, A. Upravljanje poslovanjem knjižnica pri uključivanju volontera. // Vjesnik bibliotekara Hrvatske 57, 4(2014), str. 109-134. [citirano: 2021-02-21]. Dostupno na: https://www. hkdrustvo.hr/vjesnik-bibliotekara-hrvatske/index.php/vbh/article/view/98.

26 Vujić ne navodi poslove kao element radnog mjesta. Usp. Vujić, V. Menadžment ljudskog kapitala. Rijeka: Sveučilište u Rijeci, Fakultet za turistički i hotelski menadžment Opatija, 2008. Str. 111. 
ili više zadanih poslova. Primjerice, radno mjesto knjižničara sadrži poslove koji su međusobno srodni, kao što su poslovi organiziranja poslova na svome odjelu, sudjelovanje u nabavi knjižnične građe, rad na posudbi knjižnične građe itd.

Oblikovanje poslova ima za svrhu organizacijsko usklađivanje obavljanja različitih poslovnih procesa i poslovnih funkcija knjižnice. Ono se operativno izvodi tako što se analiziraju (1) sadržaji posla (ono što radnik radi), (2) kontekst posla (uvjeti pod kojima se posao obavlja, primjerice radne grupe, subordinacija, radni i sigurnosni uvjeti i sl.) te (3) zahtjevi koji se postavljaju pred radnikom (znanje, kompetencije, vještine, osobine, obrazovanje, licence itd.). Pitanja koja mogu pomoći u oblikovanju posla mogu biti sljedeća: što se poslom obavlja, njegov tehnički i tehnološki opis, kada, kako i koliko se posao obavlja, koji je broj zadaća, kojim se redoslijedom zadaće obavljaju, koji čimbenici utječu na rad itd. ${ }^{27}$

Oblikovanje radnih mjesta predstavlja organizacijsku nadgradnju prethodno oblikovanih i definiranih poslova. Ono ima za cilj sakupiti, klasificirati i organizirati sve informacije potrebne za oblikovanje konkretnog radnog mjesta. Nakon što se sva radna mjesta opišu, potrebno ih je grupirati u organizacijske jedinice, primjerice referade, službe, timove, odjele, sekcije, sektore, uprave, direkcije, inspektorate itd. Rezultat procesa oblikovanja radnih mjesta dokument je koji može imati različite nazive, primjerice Pravilnik o ustrojstvu radnih mjesta, koji često sadrži odredbe o unutarnjoj organizaciji knjižnice.

Najčešće ustrojbene jedinice narodnih knjižnica u Republici Hrvatskoj su posudbeni odjel, odjel nabave, razmjene i obrade, služba čitaonice, računovodstvo i financijska služba, tajništvo, ravnateljstvo itd. Pojedine knjižnice, njezini odjeli i službe u svome sastavu mogu imati podružnice, ogranke, odsjeke itd. ${ }^{28}$

\subsection{Planiranje ljudskih potencijala u knjižnici}

Različitost ljudskih potencijala u odnosu na ostale resurse organizacije određuje složenost planiranja i ostalih navedenih procesa. Nedostatno i neodgovarajuće planiranje ljudskih potencijala u pravilu će imati veće negativne organizacijske i financijske posljedice nego slabo planiranje ostalih resursa gospodarskog sustava. Postoje brojni razlozi zbog kojih je planiranje potrebno postojano i pažljivo provoditi, no najvažniji su sljedeći: proces zapošljavanja, razvoja i obrazovanja ljudskih potencijala sve je skuplji i dulje traje, neučinkovitost neodgovarajućih ljudskih potencijala povećava troškove $i$ tako smanjuje uspješnost knjižnice i zadovoljstvo korisnika, na tržištu rada može nedostajati iskusnih knjižničara, a pronalaženje i

${ }_{27}$ Usp. Obradović, V.; J. Samardžija; J. Jandrić. Menadžment ljudskih potencijala u poslovnoj praksi. Zagreb: Plejada 2015. Str. 65.

28 Detaljnije o organizacijskoj strukturi knjižnice vidjeti u: Balog, A. Prema oblikovanju organizacijske strukture knjižnice. // Vjesnik bibliotekara Hrvatske 63, 1/2(2020), str. 103-106. DOI: https://doi.org/10.30754/vbh.63.1-2.789. 
angažiranje ključnih stručnjaka i specijalista može biti otežano itd. Prema tome, učinkovito planiranje ljudskih potencijala omogućava povezivanje zahtjeva sadašnjeg i budućeg poslovanja knjižnice osiguravanjem potrebnih kadrova i tako sprječava probleme i teškoće koji mogu ugroziti poslovanje.

Determinante planiranja ljudskih potencijala najčešće se dijele na vanjske (neizvjesnost okruženja, tržište rada, zakonodavstvo, uloga sindikata itd.) i unutarnje (poslovna strategija, vrsta posla i radne kvalifikacije, vremenski horizont planiranja te vrsta i kvaliteta informacija potrebnih za predviđanje). ${ }^{29}$ Vanjske determinante odnose se na različite stupnjeve neizvjesnosti u okruženju knjižnice, bilo da su u pitanju društvene, demografske, tržišne, ekonomske, financijske ili neke druge neizvjesnosti. Njihovo potpuno uklanjanje nije moguće, ali njihov utjecaj potrebno je smanjivati, njima upravljati i svoditi ih na podnošljivu mjeru. Nadalje, na tržǐštu rada može nastati nedostatak potrebnih stručnjaka s dovoljnim radnim iskustvom i željenim kompetencijama. Stoga je planiranje ljudskih potencijala potrebno sustavno voditi unutar razumnog vremenskog horizonta (primjerice između tri i pet godina).

Poslovna strategija, kao unutarnja determinanta planiranja ljudskih potencijala, određuje koje će se poslovne politike primjenjivati u knjižnici. Primjerice, hoće li knjižnica voditi politiku zapošljavanja na određeno vrijeme, imajući u vidu nestabilnost tržišta svoje djelatnosti, ili će nastojati svojim uposlenicima pružiti radnu sigurnost kako bi ih zadržala u uvjetima otvaranja atraktivnih tržišta rada. Kada knjižica zapošljava, primjerice osobe s nižim kvalifikacijama, čija je ponuda na tržištu rada velika, planiranje ljudskih potencijala može se osloniti na politiku niskih plaća i relativno veće fluktuacije uposlenih. Međutim, kada knjižnica zapošljava osobe koje imaju specijalistička znanja, vremenski horizont planiranja mora biti dulji kako bi se imalo vremena privući i zadržati visokostručne kadrove.

Da bi planiranje ljudskih potencijala bilo uspješno, ono se treba oslanjati na primjerene i dovoljno kvalitetne informacije, bilo da su one strategijske informacije (misija, ciljevi, vrste tržišta itd.), opće organizacijske informacije (organizacijska struktura, ciljevi pojedinih funkcija knjižnice, planovi razvoja itd.) ili specifične informacije (analiza poslova, programi obrazovanja uposlenika, izvori pribavljanja radnika, naknade i plaće, planovi umirovljenja itd.).

Sadržaj planiranja ljudskih potencijala odnosi se na utvrđivanje broja radnika potrebnih za potpuno, usklađeno i nesmetano funkcioniranje knjižnice. Osim broja radnika, planiranjem se obuhvaćaju njihova potrebna obilježja, primjerice obrazovanje, radno iskustvo, motivacija, osobine ličnosti itd. Takvo planiranje dio je strategijskih (dugoročnih), taktičkih (srednjoročnih) i operativnih (kratkoročnih) planova knjižnice.

Strateško planiranje ljudskih potencijala sadržavat će analizirane i interpretirane čimbenike okruženja (vanjskog i unutarnjeg, osobito anticipirane

29 Usp. Bahtijarević Šiber, F. Nav. dj., str. 189-198. 
promjene na tržištima rada), predvidljive potrebe knjižnice unutar zadanog vremenskog horizonta, planiranje profesionalnog razvoja i usavršavanja uposlenika itd. Strateško planiranje naglašeno je razvojno i temelji se na dugoročnim prognozama.

Srednjoročno planiranje ljudskih potencijala knjižnice sadržavat će analizu poslova, odnosno radnih mjesta, predvidive potrebe upošljavanja ili otpuštanja, sukcesiju rukovodećih radnih mjesta, reinženjering ljudskih potencijala itd. Kratkoročno (operativno) planiranje ljudskih potencijala knjižnice odnosi se na godišnje, kvartalne i mjesečne planove te će sadržavati odluke o popuni radnih mjesta, otpuštanja, zaključivanja ugovora o radu, pridobivanju ljudi za posao, premještanje radnika unutar ustrojbenih jedinica, planove promocije, promjene plaća, planiranje rasporeda korištenja godišnjih odmora, projekcije naknada i beneficija, praćenje i kontrolu rezultata rada uposlenika, postupke u cilju ublažavanja fluktuacije i apsentizma zaposlenih, izradu odgovarajući analiza i izvješća itd.

Proces planiranja treba rezultirati pravodobnim i potpunim informacijama o broju i profilu ljudi koji su potrebni za planirano poslovanje knjižnice, imajući u vidu dinamiku rada, troškove, zakonsku i internu regulaciju te zadovoljstvo zaposlenika. Ili drugim riječima, planiranje ljudskih potencijala knjižnice kvantitativno, kvalitativno i dinamički povezuje inpute i outpute nastojeći da pravi ljudi budu na pravom mjestu u pravo vrijeme. Planiranje ljudskih potencijala ima više etapa, od kojih su najčešće: (1) analiza postojećeg stanja ljudskih potencijala, osobito unutarnje i vanjske ponude, (2) projektiranje potrebnog broja radnika, (3) verifikacija plana predloženog plana od stane stručnjaka za ljudske potencijale i nadležnih rukovoditelja te ravnatelja knjižnice, (4) usvajanje i donošenje odluke o planovima ljudskih potencijala, (5) razrada usvojenih planova i provedba te (6) njihovo praćenje i kontrola. ${ }^{30}$

Planiranje ljudskih potencijala u knjižnici polazi od podataka na temelju kojih se može predvidjeti ponuda ljudskih potencijala. Postoje dva osnovna izvora ponude radne snage: (1) tržište rada, ili vanjska ponuda radne snage te (2) postojeći ljudski potencijali u knjižnici, odnosno unutarnja ponuda. Oba navedena izvora ponude radnika imaju svoje prednosti i nedostatke koji ovise o različitim čimbenicima, najčešće o vrsti djelatnosti, fazi životnog ciklusa organizacije, organizacijskoj kulturi, tržišnoj poziciji organizacije itd. Primjerice, ako su u knjižnici ustaljena interna promocija i razvoj profesionalne karijere, tada će iz interne ponude regrutirati rukovoditelji. Međutim, u nekim će organizacijskim okolnostima upošljavanje rukovoditelja iz vanjske ponude biti svrsishodnije, osobito onda kada su neophodne značajne promjene u organizaciji i radu koje su povezane s donošenjem tzv. teških i za zaposlenike neugodnih odluka.

30 Usp. Jurina, M. O upravljanju ljudskim potencijalima. Zaprešić: Visoka škola za upravljanje i poslovanje Baltazar Adam Krčelić s pravom javnosti, 2011. Str 85-91. 
Procesi usklađivanja potreba organizacije i ponude radne snage, bili oni vanjski ili unutarnji, stalna su aktivnost službe ili referade ljudskih potencijala. Izgradnjom cjelovitog informacijskog sustava ti će se procesi lakše obavljati. Stoga svaki uposlenik treba imati svoj dosje (ili datoteku) sa svim relevantnim podacima, primjerice osobne podatke, prebivalište, radno iskustvo, obrazovanje, specifična znanja, znanje stranih jezika itd. Preporučljivo je voditi i evidencije o kandidatima koji su se javili na neki od natječaja, ali nisu bili primljeni, evidencije o rezultatima postupaka odabira, popise i razloge napuštanja organizacije i tome slično.

Rezultat procesa planiranja ljudskih potencijala jest planski dokument. On sadrži potrebne postupke i mjere koje će poduzimati ravnatelji sa svojim službama ili referadama za ljudske potencijale prema planiranim ishodima politike ljudskih potencijala. Ti ishodi mogu biti da knjižnici: (1) nedostaje određeni broj uposlenika, (2) ima višak uposlenika, (3) treba potreban broj uposlenika, ali drugačije obrazovne strukture te (4) ima potreban broj ljudi po svim obilježjima.

U slučaju da knjižnica ima manjak uposlenika, na raspolaganju je nekoliko mogućih postupaka, primjerice smanjivanje fluktuacije i apsentizma uposlenika uklanjanjem njihovih uzroka te omogućavanja prekovremenog rada. Osim tih uobičajenih postupaka, sve se više koriste fleksibilni oblici angažiranja radnika: zapošljavanje na određeno vrijeme, privremeno (kontingentno) zapošljavanje, honorarni rad, rad na pola ili dio radnog vremena (engl. part-time), radnici na poziv (primjerice netko od umirovljenih radnika ili iz studentskog servisa itd.), angažiranje volontera, unajmljivanje radnika specijaliziranih poduzeća za povremene poslove, primjerice čišćenje, prijepis, unos podataka u računalne baze (engl. outsourcing) itd.

Kada organizaciji nedostaju određeni stručni profili, uputno je sačiniti planove i programe obrazovanja, usavršavanja i prekvalifikacija, planiranje sukcesija uposlenika koji planiraju napuštanje knjižnice, promocije, democije, premještanje na druga radna mjesta i tome slično. Ponekad će biti potrebno otpustiti one osobe koje ne mogu ili ne žele pristupiti programima stručnog obrazovanja, osposobljavanja ili prekvalifikacije te uposliti ljude potrebnog obrazovanog profila.

Operativni planovi ljudskih potencijala gospodarskog subjekta najčešće imaju sljedeće međusobno integrirane sadržaje: upošljavanja novih zaposlenika, otpuštanja zaposlenika, planove umirovljenja, planove obrazovanja, edukacije, usavršavanja i treninga, planove razvoja programa društvenog standarda uposlenika (primjerice, prehrana tijekom radnog vremena, opremanje čajne kuhinje, izleti, turističke i/ili stručne ekskurzije, plaćena rekreacija, osnivanje amaterskih sportskih, pjevačkih i drugih društva itd.), izrada i provedba planova zdravstvene zaštite radnika, pružanje besplatne pravne pomoć itd. 


\subsection{Pridobivanje, odabir, zapošljavanje i u uvođenje u rad}

Pridobivanje, odnosno pronalaženje prikladnih kandidata uvijek stvara određene troškove koji najčešće iznose između 30 \% i 70 \% iznosa godišnje plaće dotičnog posla. Čak i u uvjetima visoke nezaposlenosti, pronalaženje kandidata s odgovarajućim sposobnostima, vještinama i osobinama potrebnih za uspješno obavljanje poslova može predstavljati značajan napor. Što su poslovi za koje se traže odgovarajući kandidati složeniji i odgovorniji, potraga je skuplja, teža i dugotrajnija.

Iz opisa radnog mjesta stručna služba ili referada za ljudske potencijale knjižnice priredit će profil kandidata kojega će se nastojati izabrati među kandidatima prijavljenima za posao. Profilna obilježja kandidata za posao mogu se razvrstati na tri skupine: (1) znanja, vještine, sposobnosti potrebne za obavljanje predviđenog posla, (2) poželjne osobine ličnosti, odnosno nepoželjne osobine, (3) potrebno radno iskustvo. Znanja koja se traže od kandidata za stručne i specijalističke poslove najčešće imaju tri sloja: opća znanja i vještine, znanja koja se odnose na profesiju, struku i zanimanje te specijalistička znanja radnog mjesta, odnosno posla.

Nakon što je služba ili referada za ljudske potencijale knjižnice prikupila dovoljan broj prijava za upražnjeno radno mjesto, pristupa postupcima pojedinačne evaluacije kandidata te njihove selekcije. Evaluacija kandidata je proces kojim se uspoređuju zahtjevi posla s trenutnim obilježjima prijavljenih kandidata. Za razliku od evaluacije, selekcija je postupak izbora onog ili onih kandidata koji, između svih koju su udovoljili evaluacijskom postupku, najbolje odgovaraju zahtjevima posla. Pogrešno izabran i uposlen kandidat uzrokuje najmanje tri vrste troškova: (1) troškovi privlačenja, evaluacije i selekcije kandidata, (2) povećane troškove rada takvog neprimjerenog kandidata i (3) neostvarene potencijale (ili prihode) radnog mjesta, odnosno neostvarenu dobit. Cilj procesa selekcije jest mogućnost prihvatljive prognoze buduće radne uspješnosti kandidata za posao. Stoga je uspješan izbor odgovarajućih zaposlenika politika koja se nalazi u podlozi svih ostalih poslovnih politika poduzeća.

Za postupke profesionalne selekcije kandidata najznačajnije su razlike u sposobnostima i u osobinama ličnosti. Sposobnosti su one osobine ljudi koje predstavljaju preduvjete za realizaciju uspješnosti u nekom poslu. Premda se ljudi razlikuju po mnoštvu varijabli (interesi, percepcija, motivi, aspiracije itd.) profesionalna selekcija se najčešće vrši prema sljedeća tri obilježja: (1) intelektualnim sposobnostima (inteligencija i kreativnost), zatim prema (2) osobinama ličnosti te prema (3) kompetencijama.

Intelektualne sposobnosti odnose na sposobnost shvaćanja i rješavanja problema različite vrste obradom verbalnih, numeričkih i drugih intelektualnih spo- 
sobnosti. ${ }^{31}$ Kreativnost se najčešće opisuje kao sposobnost uočavanja problema i pronalaženja odgovarajućeg, najčešće novog, originalnog rješenja. U tom smislu, kreativnost je širi pojam od inteligencije jer objedinjuje (1) znanja i specijalistička znanja, (2) intelektualne sposobnosti (inteligenciju, divergentno mišljenje, fluentnost ideja, imaginaciju, intelektualnu fleksibilnost, osjetljivost za probleme, kreativne generalizacije, intelektualnu otvorenost, perceptivnu sposobnost), (3) osobine ličnosti (tolerancija na neizvjesnost, nekonformizam, radoznalost, samopouzdanje, neovisnost, fleksibilnost, ustrajnost, uvjerljivost, skepticizam, humor) i (4) motivaciju (za samoaktualizaciju, postignuća, radoznalost, raznolikost i istraživanje, smjele pothvate, materijalne dobiti, organizacijske uvjete i organizacijsku klimu). ${ }^{32}$

Povezanost osobina ličnosti i radne uspješnosti složenija je nego li je to slučaj s intelektualnim sposobnostima. Iskustva pokazuju da su one osobito važne u onim poslovima u kojima postoji interakcija s drugim osobama, kao što su knjižničari. Prema najšire prihvaćenom Cattellovom peterodimenzionalnom modelu ličnosti (engl. The Big Five) ličnost se sagledava u sljedećim dimenzijama: (1) ekstraverzija (otvorenost prema okolini, odnosno ekstrovertnost vs. introvertnost), (2) emocionalna stabilnost, (3) ugodnost (suradljivost, ljubaznost, pomirljivost itd.), (4) pouzdanost (savjesnost, organiziranost, postojanost itd.) te (5) radoznalost i otvorenost za iskustvo. Praksa je pokazala da su različite dimenzije ličnosti značajno povezane s radnom uspješnošću pojedinih zanimanja ili profesija.

Kompetencije, kao treće obilježje prema kojem se vrši selekcija kandidata, jesu sposobnosti osobe uspješnog obavljanja određene zadaće prema uspostavljenim radnim kriterijima ili standardima. One predstavljaju splet različitih individualnih osobina koje $\mathrm{u}$ interakciji s radnim okruženjem rezultiraju određenim radnim ili profesionalnim ponašanjem. Kao dobar primjer i prikladan orijentir razvoja knjižničarskih kompetencija u hrvatskim knjižnicama, možemo navesti ALA-ine (engl. American Library Association) kompetencijske knjižničarske jezgre iz 2009. godine. ${ }^{33}$ Kompetencijske knjižničarske jezgre koje navodi ALA jesu: (1) temelji struke, (2) građa, (3) organizacija zabilježenog znanja i informacija, (4)

\footnotetext{
31 Psiholozi su, uglavnom, suglasni da postoje različite inteligencije, primjerice fluidna, nespecijalizirana (tip A), ili kristalizirana, specijalizirana (tip B), koja se razvija pod utjecajem obrazovanja i kulture. Socijalna ili emocionalna inteligencija objedinjuje sposobnosti kontroliranja vlastitih emocija, uspostavljanja socijalnih kontakata te sposobnosti pravilnog društvenog reagiranja u određenim situacijama.

32 Usp. Bahtijarević Šiber, F. Individualne, organizacijske i društvene pretpostavke kreativnosti. // Ekonomski analitičar 10(1992), str. 23.

33 ALA's core competences of librarianship. [citirano: 2021-02-21]. Dostupno na: http://www.ala.org/educationcareers/sites/ala.org.educationcareers/files/content/careers/corecomp/corecompetences/finalcorecompstat09.pdf.
} 
tehnološka znanja i vještine, (5) informacijska služba, (6) istraživanje, (7) stalno stručno usavršavanje i cjeloživotno učenje, (8) administracija i upravljanje. ${ }^{34}$

Kada se radi o selekciji kandidata preporučljivo ju je obaviti u dvije faze ako postoji veći broj prijavljenih kandidata: (1) primarna selekcija i (2) završna selekcija. Primarna selekcija obuhvaća primjenu kriterija koji isključuju kandidate koji ne ispunjavaju uvjete radnog mjesta (primjerice, imaju neodgovarajuće obrazovanje, radno iskustvo, ponašanje, zdravlje, fizičke predispozicije itd.). Tijekom primarne selekcije pregledavaju se molbe i pisane preporuke te se vrši skupno testiranje kako bi se suzio broj kandidata za postupak završne selekcije.

Preostali kandidati ulaze u proceduru završne selekcije, koja najčešće obuhvaća telefonski razgovor, završno testiranje, provjeru i evaluaciju preporuka, intervju te probni rad. Kada se uspjeh tijekom školovanja uzima kao selekcijski kriterij, on treba biti prednost samo kada su ostali promatrani kriteriji isti ili slični. ${ }^{35}$

Selekcijske metode i tehnike kandidata za posao najčešće obuhvaćaju sljedeća vrednovanja: (1) pismene prijave na oglas ili natječaj, (2) svjedodžbe i diplome stečenog obrazovanja, (3) postojeće radno i životno iskustvo, (4) pisane preporuke bivših poslodavaca, (5) medicinsku dokumentaciju, (6) rezultate psihologijskih, situacijskih i drugih testova, (7) intervju i (8) probni rad.

Prijave na natječaj, kada se obavljaju preko unaprijed pripremljenih prijavnih obrazaca, mogu sadržavati važne informacije o kandidatu. Životopis je, također, uobičajen način prikupljanja podataka o kandidatu i služi za selekcijske postupke. Praksa je pokazala da životopisi mogu imati bolju prognostičku valjanost buduće radne uspješnosti kandidata od drugih selekcijskih metoda (osim testova intelektualnih sposobnosti). Preporuke bivših poslodavaca korisne su u procesu selekcije, ali je njihova prognostička valjanost budućeg radnog ili profesionalnog ponašanja niska. Problemi koji se odnose na preporuke jesu njihova subjektivnost i orijentiranost uglavnom na ocjene o ličnosti. Da bi bile objektivnije, preporuke bi trebale biti strukturirane te sadržavati naznaku stupnja poznavanja kandidata i njegova rada, poznavanje konkretnog posla te primjere radnog ponašanja. Telefonskom provjerom pisanih preporuka mogu se pribaviti dodatne informacije.

Psihologijski testovi predstavljaju vrlo razvijeno sredstvo selekcije kandidata za posao s obzirom na njihovu visoku prognostičku valjanost. Najčešće se koriste tri vrste testova: (1) testovi sposobnosti, od kojih su najvažniji testovi inteligen-

\footnotetext{
34 Usp. Cjeloživotno učenje. Nav. dj., str. 177.

35 Korelacija ocjena tijekom obrazovanja i radne uspješnosti čini se da nema osobit značaj. Istraživanja Ekonomskog instituta iz Zagreba između 1986. i 1990. godine pokazala su povezanost (korelacija) između ocjena osnovne i srednje škole 0,44 ; između ocjena srednje škole i fakulteta 0,23 ; između ocjena u srednjoj školi i ocjene rada samo 0,23 , a povezanost između ocjena tijekom visokog obrazovanja i ocjene radne uspješnosti 0,24 . Prema tom istraživanju dakle predikcija radne uspješnosti prema uspjehu tijekom školovanja je značajno niska. Usp. Marušić, S. Nav. dj., str. 155 .
} 
cije, testovi specifičnih sposobnosti (primjerice, perceptivnih, spacijalnih, numeričkih, verbalnih sposobnosti te rječitosti), testovi kreativnosti, testovi mehaničkih sposobnosti, testovi senzornih i psihomotornih sposobnosti, (2) testovi ličnosti i (3) testovi znanja i interesa. ${ }^{36}$

Intervju za posao, kao svrhovit razgovor tijekom kojega se nastoji što bolje upoznati kandidata za posao, najčešća je korištena selekcijska tehnika. Njegova glavna svrha jest u prikupljanje informacija o kandidatu i njegovoj sposobnosti za predviđeni posao. Također, tijekom intervjua kandidat može dobiti dio informacija o poslu za koji se prijavio, kao i o knjižnici. U procesu intervjua obje strane, i kandidat i osoba koja vodi intervju, razmjenjuju informacije te se u različitoj mjeri međusobno procjenjuju. To ovisi i o vrsti strategije koja se tijekom intervjua primjenjuje. Najčešće se koriste strategije otvorenosti i prijateljstva, zatim strategija u kojoj se naizmjence koriste ugodne i neugodne situacije, strategija rješavanja nekog hipotetskog problema (često nazivan situacijski intervju), strategija stresa, $\mathrm{u}$ kojoj se provjerava ponašanje kandidata u neugodnim okolnostima, itd. ${ }^{37}$

Uzorak posla može biti visoko pouzdan prediktor podobnosti kandidata za radno ponašanje i buduće obavljanje posla. Uzorci posla mogu biti različiti, primjerice brzina tipkanja, izrada mrežne stranice, katalogizacija knjižnične građe itd.

Probni rok je najstariji način selekcije kandidata za posao. Tijekom razdoblja probnog rada moguće je temeljito ocijeniti sva obilježja kandidata. Probni rok primjeren je kandidatima koji su prošli proces primarne i završne selekcije.

Budući da na proces selekcije kandidata utječe mnoštvo čimbenika, ta je zadaća uvijek složena i, do određene mjere, neizvjesna. Stručnjaci za ljudske potencijale nastoje relativno jednostavnim sredstvima proniknuti u kompleksna ponašanja koja su različita za različite tipove osoba u različitim situacijama. Dobro je znati da korištenjem najboljih selekcijskih metoda i tehnika te valjanog izbora prognostičkih prediktora, predvidljivost budućeg radnog ponašanja kandidata ne može se sa sigurnošću utvrditi. Proces primarne i završne selekcije kandidata za određeni posao uvijek završava s određenim stupnjem neizvjesnosti. Tu neizvjesnost ravnatelji nastoje uklanjati ili barem umanjivati zaključivanjem ugovora o radu na određeno vrijeme.

\footnotetext{
36 Važno je znati da, ako se provodi psihološko testiranje, tada je potrebno angažirati psihologa osposobljenog za uža područja profesionalne psihološke selekcije kandidata, koji je licenciran za uporabu testova inteligencije, testova osobnosti itd.

37 Dobro je znati da intervju, kao instrument selekcije kandidata, često može imati značajne manjkavosti. Jedna od njih je ta da čovjek, u pravilu, nije pouzdan mjerni instrument pa to ne može biti niti osoba koja provodi intervju. Ostale manjkavosti intervjua odnose se na kandidata (primjerice dob, spol, fizički izgled, stavovi, politička pripadnost itd.), na osobu koja provodi intervju (pogreške u procjenjivanju, predrasude, iskustvo u intervjuiranju itd.) i na samu situaciju intervjua (neodgovarajuća priprema, situacija na tržištu rada, doba radnog dana itd.). Usp. Torrington, D. ; L. Hall. Personnel management: A New approach. New York: Prentice Hall, 1991. Str. 314.
} 
Nakon zasnivanja radnog odnosa i zaključivanja ugovora o radu slijedi postupak uvođenja novog uposlenika u posao. Najčešći je oblik uvođenja djelatnika u posao pripravnički (ili vježbenički) staž koji se odvija pod nadzorom mentora. On se organizira i provodi za one koji se prvi put zapošljavanju u nekoj struci. Uposlenici koji su završili svoj pripravnički staž, mogu pristupiti polaganju stručnog ispita. ${ }^{38}$ Osobe koje imaju radno iskustvo i položen stručni ispit, uvode se u posao standardnim procedurama, s probnim rokom ili bez njega. Te procedure dobro je normirati i provoditi kako bi uvođenje u posao bilo učinkovito i jednostavnije.

Uvođenje u posao ima nekoliko aspekata: (1) dovršavanje obrazovnog i stručnog profila primljenog radnika putem seminara, treninga, određivanjem mentora itd.; (2) uklanjanje socijalnih otpora koje nerijetko pruža skupina u koju ulazi novozaposleni; (3) prilagodba novom radnom, organizacijskom i socijalnom okruženju koja može trajati od nekoliko tjedana do nekoliko mjeseci te podrazumijeva upoznavanje s neposrednim rukovoditeljima, s radnicima s kojima će novouposleni radnik surađivati, upoznavanje s normativnim aktima i ostalim dokumentima, procedurama, stilom rukovođenja, mogućnostima obrazovanja i napredovanja, procesima i načinima rada, s ciljevima organizacijske jedinice i poduzeća itd.

\subsection{Motiviranje i nagradivanje}

Nerijetko se susrećemo s tvrdnjom kako je motiviranje radnika povezano i sa sposobnošću vođenja nadležnih rukovodilaca od kojih se očekuje, između ostalog, oblikovanje motivirajućeg radnog okruženja. Ta je tvrdnja samo djelomično točna jer nečija motivacija ovisi i o sposobnostima samomotiviranja, odnosno o razvijenosti tzv. emocionalne inteligencije. Razmotrimo u nastavku teksta povezanost i međusobne utjecaje rukovođenja, upravljanja ljudskim potencijalima te motiviranosti u radu.

Premda je motivacija pojam koji potiče iz područja psihologije, svoju uporabu dobio je u brojnim drugim znanostima. Motiv, kao polazni pojam, predstavlja unutarnji poticaj osobe prema zadovoljavanju svoje potrebe i želje. Te potrebe mogu biti fiziološke (primjerice, zrak, hrana, voda, san itd.), egzistencijalne (primjerice, zaštita tijela, sigurnost skupine, spolnost itd.), društvene (kultura, zabava, prihvaćanje, poštovanje, religija itd.), psihološke (prijateljstvo, podrška, samopotvrđivanje itd.). Motivacija se najšire može definirati kao zbroj i međuodnos unutarnjih čimbenika koji izrastaju iz potreba i želja neke osobe i koje tu osobu pokreću, usmjeravaju te održavaju emocionalnu, fizičku i intelektualnu energiju usmjerenu na svrhovito ponašanje kako bi se dotična potreba i želja zadovoljila. ${ }^{39}$

\footnotetext{
38 Stručni ispiti, dopunski stručni ispiti te razlikovni stručni ispiti u knjižničarskoj struci polažu se sukladno Pravilniku o uvjetima i načinu stjecanja stručnih zvanja u knjižničarskoj struci, nav. dj.

39 Usp. Weihrich, H; H. Koontz. Menadžment. Zagreb: Mate, 1994. Str. 463.
} 
Motiviranje je, za razliku od motivacije, proces kojima se nastoji usmjeriti i održavati napor nekog pojedinca ili skupine kako bi se ostvarile individualne ili skupne potrebe. Da bi motivacija bila učinkovita i uspješna, knjižnice trebaju što bolje i spretnije povezati i poistovjetiti ciljeve ustanove s potrebama i željama pojedinaca i radnih grupa. Drugim riječima, proces motiviranja podrazumijeva da radnik i radnici, odnosno pojedinci, radne skupine i radni timovi, trebaju u postizanju organizacijskih ciljeva i zadataka prepoznavati ispunjavanje vlastitih potreba, želja i preferencija.

Motiviranje u organizacijama sadrži dinamički splet složenih psiholoških, socio-psiholoških, organizacijskih i upravljačkih procesa. Na motiviranje utječu brojni čimbenici, primjerice osobna obilježja pojedinca (njegove potrebe, percepcije, aspiracije, preferencije, interesi, očekivanja, stavovi, vrijednosti itd.), obilježja posla ili radnog mjesta (primjerice, zanimljivost posla, njegova složenost, odgovornost u radu, autonomnost u donošenju odluka, mogućnost postignuća, značaj posla, povratne informacije, nagrade i kompenzacije itd.) te obilježja poslovne organizacije (primjerice, proces rada, radna okolina, stil rukovođenja, politika nagrađivanja, organizacijska kultura i organizacijska klima itd.). Da bi se izgradila i održala zadovoljavajuća razina motivacije, potrebno je u organizaciji izraditi motivacijski sustav. Taj sustav treba objedinjavati psihološke, socio-psihološke, organizacijske i upravljačke elemente te im pridodati pojedine dijelove politike ljudskih potencijala koji su dostatno razrađeni i u praksi primijenjeni, primjerice politika materijalnog nagrađivanja radnih učinaka i nematerijalnog stimuliranja, politika poticanja obrazovanja i stručnog usavršavanja, omogućavanje razvoja inovativnosti, kreativnosti, sudjelovanja u upravljanju, napredovanja i karijere, radne etike itd. Kazne, bile one materijalne (novčane) ili nematerijalne, odnosno simbolične (primjerice opomene, javne opomene, opomene pred otkaz, ukori, premještaj na drugo radno mjesto itd.) mogu biti motivatori čije djelovanje treba biti preventivno i ograničeno na osiguravanje minimalnih radnih učinaka. Kaznama se motivacija ne može unaprijediti, ali se mogu spriječiti destruktivna ponašanja te djelomice prevenirati demotiviranost.

Motiviranje uposlenika stalna je dužnost ravnatelja i ostalih rukovodilaca knjižnice. Bez tog organizacijskog napora knjižnica će stagnirati i zaostajati u svome razvoju u odnosu na razvoj svog okruženja. Motiviranje se obavlja izborom prikladnih motivatora te njihovom dinamičkom kombinacijom. Motivatori su materijalne i nematerijalne vrijednosti koje zaposlenika potiču na rad te radno i organizacijsko ponašanje. Motivatori nemaju jednaku vrijednost za svaku osobu, već imaju jači ili slabiji odraz u percepciji različitih zaposlenika. Stoga je njima moguće upravljati, ali i manipulirati.

Sustavi motiviranja zaposlenika, koji su operativni izraz strategije nagrađivanja, temelje se na općoj poslovnoj politici nagrađivanja u knjižnici. Politika nagrađivanja postavlja si odgovarajuće ciljeve, od kojih se najčešće navode slje- 
deći: privlačenje i zadržavanje najkvalitetnijih ljudi, osiguravanje da zaposlenici kvalitetno izvršavaju svoje poslove, poticanje njihove kreativnosti i inovativnosti uz uspješno odgovaranje na izazove tekućih i razvojnih problema te pomaganje uposlenicima u poistovjećivanju s knjižnicom i njenom održivom razvoju. ${ }^{40}$

Nagrađivanje zaposlenika koristi dvije osnovne skupine motivatora: (1) materijalno nagrađivanje i stimulacije i (2) nematerijalno nagrađivanje. Navedene skupine motivatora mogu se odnositi na pojedinačnog uposlenika, zatim na radnu grupu, na projektni tim te na knjižnicu u cjelini.

Materijalno nagrađivanje kao motivacijska stimulacija javlja se u nekoliko oblika. Plaće i dodaci na plaće glavni su motivatori koji trebaju počivati na pravičnom sustavu vrednovanja poslova, odnosno njegove složenosti, traženih odgovornosti, potrebnih kvalifikacija, uvjeta rada te radnih učinaka i postignuća. Plaćene beneficije drugi su oblik materijalnog nagrađivanja i odnose se, primjerice, na plaćeni godišnji odmor, financiranje trećeg stupa mirovinskog osiguranja, životno osiguranje, dodatno zdravstveno osiguranje, nadoknadu školarina, plaćene slobodne dane potrebne za obrazovanje itd. Pogodni su i drugi oblici materijalnih motivatora, primjerice plaćena prehrana tijekom radnog vremena, korištenje čajne kuhinje, mogućnost korištenja službenog vozila, rezervirano parkirno mjesto, položaj i oprema ureda, prilagođeno radno vrijeme itd. Poticaji kao oblici materijalnih motivatora odnose se na plaćeno sudjelovanje u radu tijela uprave (odbora, komisija, povjerenstva, radne grupe, projektnog tima itd.). I na kraju, povremene prigodne nagrade za, primjerice, znatne uštede, unaprjeđenja i racionalizacije, velike poslovne uspjehe, jubilarne nagrade za dugogodišnji rad u knjižnici itd. mogu biti pomoćni motivatori.

Nematerijalno nagrađivanje i motiviranje imaju mjerljive utjecaje na ponašanja radnika samo ako su glavni materijalni motivatori već prisutni u dovoljnom broju i veličini. Razlog te pojave leži u činjenici da glavnina nematerijalnih motivatora ima svoj značajni utjecaj na potrebe višeg reda. Najčešći nematerijalni motivatori su: oblikovanje posla, obogaćivanje posla, rotacija posla, odgovarajući rukovodeći stil, sudjelovanje zaposlenika u upravljanju i rukovođenju, dodjela priznanja za postignute uspjehe, kao što su zahvalnice, plakete ili odličja, postojanje povratnih informacija o rezultatima rada, razvijena stimulativna organizacijska kultura, postojanje ugodne radne klime, mogućnost rada od kuće, klizno radno vrijeme, mogućnost biranja suradnika, mogućnost rekreacije, skupni izleti i sportske igre, proslave obljetnica, praznika i blagdana uz zajedničke objede itd.

40 Usp. Colquitt, A.; J. A. LePine; M. J. Wesson. Organizational behavior. New York: McGraw-Hi11, 2010. Str. 98. 


\subsection{Obrazovanje i osposobljavanje}

Sve brži razvoj suvremene znanosti, a s njome povezan razvoj i rast tehnike i tehnologije, osobito informatičkih tehnologija i internetskih komunikacija općenito mijenja društvo, a time i okruženja u kojima posluju pravni subjekti. Bez obzira na to jesu li knjižnice u okruženju koje obilježavaju veća ili manja dinamika promjena, one se tim promjenama moraju moći prilagođavati. Prema tome, pravovremena prilagodba ljudskih potencijala nastalim promjenama okruženja predstavlja neizbježan zahtjev strateškog razvoja knjižnice.

Prilagodbe ljudskih potencijala knjižnice promjenama društveno-ekonomskog okruženja, višeslojne su i kreću se od psiholoških, socioloških, kulturoloških, organizacijskih, poslovnih do obrazovnih i pedagoških, tehnoloških i drugih. Postojeće obrazovne ustanove najčešće nisu u stanju predvidjeti nadolazeće napredne tehnološke promjene, a s njima povezano povećanje opće kompleksnosti i neizvjesnosti rada. Otuda znanja usvojena tijekom formalnog obrazovanja, premda i dalje potrebna, nisu dostatna tijekom radnog vijeka. Stoga cjeloživotno učenje i obrazovanje, kao jedan od oblika stjecanja znanja i vještina, treba rezultirati kontinuiranim prilagodbama organizacijskog ponašanja suvremenim promjenama okruženja.

Sustav osposobljavanja višeslojan je i ima nekoliko segmenata od kojih se svaki može pojaviti u poslovanju knjižnice: (1) obrazovanje, odnosno redovno ili izvanredno školovanje od osnovne škole do doktorata, čime se stječe široko i opće obrazovanje; (2) odgoj je formiranje, razvoj i oblikovanje vrijednosti, stavova i navika potrebnih tijekom života i obnašanja stečenih i pridodanih uloga; (3) izobrazba, odnosno stručno osposobljavanje kojima se stječu uža znanja i vještine potrebni za određena zanimanja; (4) stručno usavršavanje ima sljedeće oblike: (4.1) specijalizacija, kojom se produbljuju znanja i vještine jednog segmenta zanimanja, (4.2) dokvalifikacija, kojom se dodaje novi segment znanja i vještina (4.3) inoviranje znanja, kojim se nadopunjuju nove spoznaje u struci; (5) prekvalifikacija, kojom se mijenja zanimanje te koje može imati nekoliko stupnjeva (5.1) u prvom stupnju mijenjaju se poslovi unutar određenog zanimanja, (5.2) u drugom stupnju mijenja se zanimanje unutar određene struke, (5.3) u trećem stupnju prekvalifikacije mijenja se i struka i zanimanja. ${ }^{41}$

Formalno obrazovanje svih razina temelj je i polazište kasnijeg razvoja i usavršavanja ljudskih potencijala u knjižnicama i njima srodnim ustanovama. U Hrvatskoj postoji nekoliko studijskih programa različitih obrazovnih razina namije-

\footnotetext{
41 Vodič kroz sustav obrazovanja u Republici Hrvatskoj [citirano: 2021-02-21]. Dostupno na: https://mzo.hr/sites/default/files/links/hrvatski_obra zovni_sustav.pdf.; usp. i: Nacionalna klasifikacija zanimanja. Nav. dj.
} 
njenih knjižničarima i informacijskim stručnjacima koji se desetljećima izvode na više visokih učilišta. ${ }^{42}$

Obrazovanje koje slijedi nakon završenog formalnog školovanja i ulaska u svijet rada, ima sljedeće glavne ciljeve: (1) motivirati na cjeloživotno učenje, (2) nadopuniti znanja i vještine nastale nakon završetka formalnog obrazovanja, (3) stjecanje znanja i vještina koji se nisu stjecali tijekom formalnog obrazovanja, primjerice interpersonalne vještine i sposobnost pregovaranja, organizacijska učinkovitost i vodstvo, prepoznavanje problema, kreativno rješavanje problema, sposobnost prilagođavanja promjenama u radnoj okolini, sposobnost razvoja vlastite karijere, razvoj sposobnosti čitanja, pisanja, govorenja i slušanja itd. ${ }^{43}$ Tim ciljevima treba dodati cilj (4) svladavanje samostalnog učenja i cjeloživotnog usavršavanja.

Prema Hrvatskom klasifikacijskom okviru glavni rezultati učenja jesu stečene odgovarajuće kompetencije u širem smislu (lat. competere: biti sposoban) koje su potrebne za obavljanje nekog zanimanja, profesije ili poluprofesije. ${ }^{44}$ One objedinjuju tri područja: znanja, vještine i kompetencije u užem smislu..$^{45}$ Znanje se najčešće označava kao skup organiziranih informacija koje je stekla neka osoba. Objedinjuje deklarativno ili konceptualno znanje koje sadrži činjenice te proceduralno ili operativno znanje. Za razliku od znanja, vještine su usavršena operativna znanja kojima se učinkovito i spretno primjenjuju stečena znanja i izvode naučene i uvježbane radnje. Vještine se mogu razvrstati u (1) psihomotoričke ili praktične vještine (fizička spretnost uporabe postupaka, instrumenata, alata i materijala), (2) spoznajne ili intelektualne vještine (kreativno razmišljanje, pronalaženje rješenja

42 Više o obrazovanju knjižničara vidi Petr Balog, K.; S. Faletar Tanacković. Obrazovanje knjižničara i informacijskih stručnjaka u Republici Hrvatskoj s naglaskom na studij informatologije Odsjeka za informacijske znanosti Filozofskog fakulteta Sveučilišta u Osijeku. // 5. stručni skup s međunarodnim sudjelovanjem, Okrugli stol: Prvih dvadeset 21. stoljeća u knjižničarstvu. / uredili M. Kretić Nađ i R. Benić. Beli Manastir: Gradska knjižnica Beli Manastir, 2020. str. 57-87; Dragija Ivanović, M.; B. Badurina. Procjena dobivenih knjižničnih kompetencija završenih studenata informacijskih znanosti u Hrvatskoj. // Vjesnik bibliotekara Hrvatske 63, 1/2(2020), str. 703-746. [citirano: 2021-02-21]. Dostupno https://www.hkdrustvo.hr/vjesnik-bibliotekara-hrvatske/index. $\mathrm{php} / \mathrm{vbh} /$ article/view/779/667.

${ }^{43}$ Usp. Carnevale, A. P.; L. J. Gainer; A. S. Meltzer. Workplace basic: The Essential skill employers want. San Francisco: Jossey-Bass, 1990. Str. 109.

44 Pojmovnik Hrvatskog klasifikacijskog okvira. [citirano: 2021-02-21]. Dostupno na: http://www.hzz.hr/UserDocsImages/Pojmovnik_Hrva tskoga_kvalifikacijskog_okvira.pdf.

45 Prema definiciji Agencije za znanost i visoko obrazovanje, kompetencije predstavljaju dinamičnu kombinaciju kognitivnih i meta-kognitivnih vještina, znanja i razumijevanja, međuljudskih, intelektualnih i praktičnih vještina te etičkih vrijednosti. Razvoj tih kompetencija cilj je svakoga obrazovnog programa. Kompetencije se razvijaju u svim programskim jedinicama $i$ utvrđuju u različitim stupnjevima programa. Neke su kompetencije područno specifične (svojstvene određenoj disciplini), dok su druge generičke (zajedničke svim programima). Uobičajeno je da se razvoj kompetencija odvija ciklički i na integriran način tijekom cijelog programa. Usp. Pojmovnik. Kompetencije. // Agencija za znanost i visoko obrazovanje. [citirano: 2021-02-21]. Dostupno na: https://www.azvo.hr/hr/pojmovnik/78-kompetencije. 
u određenoj struci te (3) socijalne vještine (stvaranje i razvijanje društvenih odnosa). Kompetencije u užem smislu imaju dvije sastavnice: samostalnost u djelovanju, koja označava pravo na vlastito upravljanje te odgovornost, koja označava preuzimanje obveze izvršenja preuzetih zadaća. ${ }^{46}$

Cjeloživotno učenje usko je povezano s razvojem ljudskih potencijala, odnosno s obrazovanim aktivnostima. Pojmovi cjeloživotnoga obrazovanja (engl. lifelong education) ili cjeloživotnoga učenja (engl. lifelong learning) nastali su 20-ih godina prošlog stoljeća u Engleskoj. Sam koncept nastajao je i oblikovao se nakon Drugog svjetskog rata u razvijenim zemljama zapadne i sjeverne Europe, a uobličio ga je UNESCO (engl. United Nations Educational, Scientific and Cultural Organization; hrv. Organizacija Ujedinjenih naroda za obrazovanje, znanost i kulturu) 1960. godine R. H. Dave je za cjeloživotno učenje napisao da ono:

„(...) zahtijeva da se obrazovanje sagleda u njegovom totalitetu. Ono pokriva formalni, neformalni i informalni oblik obrazovanja i pokušava integrirati i artikulirati sve strukture i faze obrazovanja duž vertikalne i horizontalne dimenzije. Ono je također karakteristično po svojoj fleksibilnosti što se tiče vremena, prostora, sadržaja, načina učenja i stoga zahtijeva samoupravljivo učenje, dijeleći nečije prosvjetljenje s drugima i prihvaćajući različite stilove i strategije učenja“". ${ }^{47}$

Prema prijedlogu Pojmovnika Hrvatskog klasifikacijskog okvira, cjeloživotno obrazovanje objedinjuje sve oblike učenja tijekom života: formalno učenje koje se izvodi u ovlaštenim ustanovama i za koje se izdaje javna isprava, neformalno učenje koje se organizirano izvodi i za koje se ne izdaje javna isprava, te informalno učenje koje označava neorganizirane aktivnosti učenja tijekom svakodnevnih aktivnosti. ${ }^{48}$

Vijeće Europske unije donijelo je 2018. godine preporuku o osam ključnih kompetencija za cjeloživotno učenje: (1) poboljšanje postignuća u osnovnim vještinama (pismenost, matematička pismenost i osnovne digitalne vještine) i podupiranje razvoja kompetencije učiti kako učiti, što čini temelj cjeloživotnog učenja i sudjelovanja u društvu koji se stalno unaprjeđuje; (2) podizanje razine osobne i socijalne kompetencije te kompetencije učiti kako učiti za poboljšanje zdravog i prema budućnosti usmjerenog načina života; (3) poticanje usvajanja kompetencija u području prirodoslovlja, tehnologije, inženjerstva i matematike (STEM), uzimajući u obzir njihovu povezanost s umjetnošću, kreativnošću i inovacijama

46 Priređeno prema Šverko, B. Ljudski potencijali: Usmjeravanje, odabir i osposobljavanje. Zagreb: Hrvatska sveučilišna naklada, 2012. Str. 119-121.

47 Foundations of lifelong education. / ed. Dave, R. H. New York: Pergamon Press, 1976. Str. 35 36. Citirano prema: Pastuović, N. Cjeloživotno učenje i promjene u školovanju. // Odgojne znanosti 10, 2(2008), str. 254. [citirano: 2021-02-21]. Dostupno na: https://hrcak.srce.hr/file/46484. 48 Usp. Pojmovnik Hrvatskog klasifikacijskog okvira. Nav. dj., str. 18. 
te motiviranje više mladih, osobito djevojčica i mladih žena, za odabir zanimanja u području STEM-a; (4) povećanje i poboljšanje razine digitalnih kompetencija u svim fazama obrazovanja i osposobljavanja te u svim segmentima stanovništva; (5) razvoj poduzetničkih kompetencija, kreativnosti i osjećaja inicijative (...); (6) poboljšanje razine jezičnih kompetencija službenog i drugih jezika te podupiranje učenika u učenju različitih jezika značajnih za njihovu radnu i životnu sredinu i kojima se može doprinijeti prekograničnoj komunikaciji i mobilnosti; (7) poticanje razvoja kompetencija građanstva s ciljem jačanja svijesti o zajedničkim vrijednostima $(. .$.$) ; (8) podizanje svijesti svih učenika te nastavnog osoblja o važ-$ nosti stjecanja ključnih kompetencija i njihova odnosa prema društvu. ${ }^{49}$

Metode obrazovanja na poslu najčešće se primjenjuju kada zaposlenik treba neposredno sudjelovati u poslu, odnosno kada mu je potreban individualan trening, zatim kada se obrazuje manja skupina, primjerice do pet ili šest osoba, kada je odsutnost radnika ili preskupa ili nemoguća te kada skupa oprema i sigurnosna ograničenja isključuju druge metode. Metode obrazovanja na poslu odnose se na: (1) individualne instrukcije (zaposlenik se obrazuje na radnom mjestu pod nadzorom instruktora); (2) rotaciju posla (zaposlenik stječe radna i druga iskustva obavljanjem različitih poslova); (3) naukovanje, odnosno stručnu praksu (radnik, odnosno učenik dio obrazovanja provodi u školi, a dio u organizaciji, (4) studentsku praksu (student obavlja svoju obveznu praksu na odgovarajućim poslovima) (5) pripravnički staž (obavlja se nakon studija i sadrži stručnu pripravu za određeni posao prema razrađenom programu obučavanja, praćenja i ocjenjivanja, (6) mentorstvo (pružanje stručne i psihološke pomoći novom zaposleniku). ${ }^{50}$

IFLA-ine Smjernice za stalno stručno usavršavanje: Načela i primjeri dobre prakse navode sadržaje koji objedinjuju teme koje se odnose na (1) knjižničarske i informacijske stručnjake, (2) poslodavce, odnosno knjižnice i njima srodne organizacije (udruge, vladina tijela i druge entitete koji su povezni s razvojem knjižnica), (3) nastavne programe knjižničarstva i informacijskih znanosti te (4) organizatore izobrazbe cjeloživotnog učenja u području knjižničarstva i informacijskih znanosti. ${ }^{51}$ Iz prethodnog se može reći da su navedeni sadržaji Smjernica stručni okvir dovoljno širok i prikladan za organiziranje i izvođenje programa cjeloživotnog stručnog usavršavanja knjižničara i informacijskih stručnjaka.

Prema članku 14. novog Pravilnika o matičnoj djelatnosti knjižnica u Republici Hrvatskoj, među zadaće matičnih knjižnica ubraja se osposobljavanje djelatnika

49 Usp. Preporuka Vijeća Europske Unije od 22. svibnja 2018. o ključnim kompetencijama za cjeloživotno učenje (2018/C 189/91). [citirano: 2021-02-21]. Dostupno na:

https://eur-lex.europa.eu/legal-content/HR/TXT/PDF/?uri=CELEX:32018H0604(01)\&from=BG.

50 Priređeno prema Bahtijarević Šiber, F.: Nav. dj., str. 745-753.

51 Usp. IFLA guidelines for continuing professional development: Principles and best practices. 2016. [citirano: 2021-02-21]. Dostupno na: https://www.ifla.org/files/assets/cpdwl/guidelines/ ifla-guidelines-for-continuing-professional-development.pdf. 
matičnih knjižnica za obavljanje stručnog nadzora i poticanje rada županijskih i sveučilišnih matičnih razvojnih službi, poticanje i organiziranje trajnog stručnog usavršavanja djelatnika u matičnim knjižnicama i suradnja pri izradi programa izobrazbe knjižničara te sudjelovanje u organizaciji savjetovanja, seminara i drugih oblika stručnog usavršavanja. ${ }^{52}$

U Nacionalnoj i sveučilišnoj knjižnici u Zagrebu osnovan je 2002. godine Centar za stalno stručno usavršavanje knjižničara koji provodi bodovane programe cjeloživotnog učenja i stalnog stručnog usavršavanja knjižničara i informacijskih stručnjaka. Tečajevi su prema sadržajima svrstani u devet modularnih kategorija te se izvode na dva načina - klasično ili mrežno, odnosno kao webinari. ${ }^{53}$ Centar donosi godišnje programe stalnog stručnog usavršavanja te godišnja izvješća. ${ }^{54}$

\section{Zaključak}

(1) Upravljanje ljudskim potencijalima (ili resursima) općenito se smatra širokim i složenim područjem u svim organizacijama, pa tako i u knjižnicama. Ta složenost je, između ostalog, zbog izražene interdisciplinarnosti te povezanosti s antropologijom, psihologijom, sociologijom, socijalnom pedagogijom, industrijskom psihologijom, pedagogijom, odnosno andragogijom, s kulturologijom, komunikologijom itd.

(2) S obzirom na to da ravnatelji knjižnica i drugi rukovoditelji u knjižnicama u pravilu nemaju specijalistička znanja iz područja organizacije, rukovođenja, ljudskih potencijala, financija, računovodstva, poslovanja, itd., bilo bi dobro prirediti i provoditi odgovarajuće programe koji bi im, u procesu cjeloživotnog učenja (ili stalnog stručnog osposobljavanja), omogućili stjecanje nedostajućih znanja i potrebnih kompetencija iz navedenih područja. Ako bi se sadašnjim i budućim ravnateljima knjižnica omogućilo odgovarajuće licenciranje u području upravljanja i rukovođenja to bi nedvojbeno pridonijelo povećanju učinkovitosti poslovanja knjižnice i njezine općenite organizacijske i društvene uspješnosti.

(3) Stručni i znanstveni tekstovi koji se odnose na knjižnice i knjižnično poslovanje najčešće tematiziraju procese obrazovanja, odnosno procese cjeloživotnog učenja knjižničnih djelatnika. Ostala područja upravljanja ljudskim potencijalima u knjižnicama i knjižnicama srodnim ustanovama, primjerice, planiranje ljudskih

52 Usp. Pravilnik o matičnoj djelatnosti i sustavu matičnih knjižnica u Republici Hrvatskoj. // Narodne novine 81, 1506/2021. [citirano: 2021-09-02]. https://narodne-novine.nn.hr/clanci/sluzbeni/2021_07_81_1506.html.

53 Centar za stalno stručno usavršavanje knjižničara. [citirano: 2021-02-21]. Dostupno na: http://cssu.nsk.hr.

54 Program Centra za stalno stručno usavršavanje knjižničara u Republici Hrvatskoj u 2021. godini predviđa više od 70 tečajeva kojeg će izvoditi više od 90 predavača, sveučilišnih profesora, knjižničara i informacijskih stručnjaka. [citirano: 2021-02-21]. Dostupno na: http://cssu.nsk.hr/ wp-content/uploads/2021/02/PROGRAM-CSSU-A-2021.pdf. 
potencijala, pribavljanje, odabir, zapošljavanje i uvođenje u rad, motiviranje i nagrađivanje, slabije su zastupljena ili ih uopće nema. Taj tematski deficit još je više uočljiv kada je riječ o tekstovima koja razmatraju neknjižnične djelatnike kao jednako važnog dijela ljudskih potencijala knjižnice.

(4) S obzirom na odgovornosti u donošenju upravljačkih odluka, potrebno je istražiti zanimanja, obrazovne profile te knjižnične kompetencije koje imaju članovi upravnih vijeća knjižnica u Republici Hrvatskoj. Isto takvo istraživanje bilo bi dobro provesti u odnosu na članove knjižničnih odbora knjižnica koje su u sastavu. Izvjesno je da članovi navedenih upravnih tijela imaju potrebnu razinu obrazovanja. Međutim, potrebno im je omogućiti stjecanje odgovarajućih osnovnih znanja koje se odnose osobito na knjižnično poslovanje te minimalna znanja u odnosu na područja neknjižničnog poslovanja, primjerice financija, računovodstva, arhivistike, informatike, zaštite na radu itd. Te dodatne i dopunske edukacije mogu se provoditi unutar izvrsno uspostavljenog sustava cjeloživotnog obrazovanja pri Nacionalnoj i sveučilišnoj knjižnici u Zagrebu.

Navedena izreka s početka ovoga teksta kako je „kadrovska politika osnova svake politike", nastala u povijesnom kontekstu političke diktature i strahovlade, zavodljivo prikriva svoj pravi sadržaj i svrhu. Je li doista kadrovsko popunjavanje najvažnija funkcija rukovođenja na koju se oslanjaju sve ostale funkcije? Kada je rukovođenje ljudskim potencijalima, ili ljudskim resursima, ili kadrovima dobro i učinkovito, tada je ono produktivan dio koji jednakovrijedno kao i ostale funkcije pridonosi uspješnom funkcioniranju organizacije. Međutim, kada to nije, postaje naglašen, a nerijetko glavni problem u poslovanju koje se odražava na sve ostale funkcije rukovođenja, a osobito na funkciju upravljanja.

\section{I T E R A T U R A}

Agencija za znanost i visoko obrazovanje. Popis reguliranih profesija u Republici Hrvatskoj. [citirano: 2020-10-30]. Dostupno na:

https://www.azvo.hr/images/stories/enic/Popis_reguliranih_profesija_u_Republici_Hrvatskoj_3.1.2019.pdf.

ALA-ine kompetencije jezgre knjižničarstva. // Cjeloživotno učenje knjižničara: ishodi učenja i fleksibilnost. / uredile Horvat, A. i Machala, D. Zagreb: Nacionalna i sveučilišna knjižnica, 2009. str. 177-180. [citirano: 2021-02-21]. Dostupno na: https:// www.nsk.hr/cuk/cuk.pdf.

Aparac-Gazivoda, T. Teorijske osnove knjižnične znanosti. Zagreb: Filozofski fakultet, Zavod za informacijske studije, 1993. 
Aparac-Jelušić, T.; S. Faletar Tanacković. Knjižnična arhitektura: Prostor, kultura, identitet. Zagreb: Ljevak, 2020.

Bahtijarević Šiber, F. Individualne, organizacijske i društvene pretpostavke kreativnost. // Ekonomski analitičar 10(1992), 17-27.

Bahtijarević Šiber, F. Management ljudskih potencijala. Zagreb: Golden marketing, 1999.

Balog, A. Prema oblikovanju organizacijske strukture knjižnice. // Vjesnik bibliotekara hrvatske 63, 1/2(2020), 83-107. DOI: https://doi.org/10.30754/vbh.63.1-2.789.

Balog, A. Prema teorijskim ishodištima i primjeni modela rukovođenja. // Vjesnik bibliotekara Hrvatske 62, 2(2019), 67-87. [citirano: 2021-02-21]. DOI: https://doi. org/10.30754/vbh.62.2.761.

Balog, A. Upravljanje poslovanjem knjižnica pri uključivanju volontera. // Vjesnik bibliotekara Hrvatske 57, 4(2014), 109-134. [citirano: 2021-02-21]. Dostupno na: https:/www.hkdrustvo.hr/vjesnik-bibliotekara-hrvatske/index.php/vbh/article/ view/98.

Carnevale, A. P.; L. J. Gainer; A. S. Meltzer. Workplace basic: The Essential skill employers want. San Francisco: Jossey-Bass, 1990.

Centar za stalno stručno usavršavanje knjižničara. [citirano: 2021-02-21]. Dostupno na: http://cssu.nsk.hr.

Colquitt, J.; J. A. LePine; M. J. Wesson. Organizational behavior. New York: McGraw-Hill, 2010.

Ćupurdija, M.; B. Moslavac; A. Balog. Upravljanje ljudskim potencijalima i radni odnosi. Rijeka: Libertin naklada, 2019.

Dragija Ivanović, M.; B. Badurina. Procjena dobivenih knjižničnih kompetencija završnih studenata informacijskih znanosti u Hrvatskoj. // Vjesnik bibliotekara Hrvatske 63, 1/2(2020), 703-746. DOI: https://doi.org/10.30754/vbh.63.1-2.779.

Foundations of lifelong education. / ed. Dave, R. H. New York: Pergamon Press, 1976.

IFLA guidelines for continuing professional development: Principles and best practices, München: Saur, 2016. [citirano: 2021-02-21]. Dostupno na:

https://www.ifla.org/files/assets/cpdwl/guidelines/ifla-guidelines-for-continuing-professional-development.pdf.

IFLA-ine smjernice za narodne knjižnice. / uredili C. Koontz i B. Gubbin. Zagreb: Hrvatsko knjižničarsko društvo, 2011.

Jurina, M. O upravljanju ljudskim potencijalima. Zaprešić: Visoka škola za upravljanje i poslovanje Baltazar Adam Krčelić s pravom javnosti, 2011.

Kompetencije informacijskih stručnjaka 21. stoljeća. // Cjeloživotno učenje knjižničara: Ishodi učenja i fleksibilnost. / uredile A. Horvat i D. Machala. Zagreb: Nacionalna i 
sveučilišna knjižnica u Zagrebu, 2009. Str. 171-177. [citirano: 2021-02-21]. Dostupno na https://www.nsk.hr/cuk/cuk.pdf.

Kompetencije. // Agencija za znanost i visoko obrazovanje. [citirano: 2021-02-21]. Dostupno na: https://www.azvo.hr/hr/pojmovnik/78-kompetencije.

Marušić, S. Upravljanje ljudskim potencijalima. Zagreb: ADECO, 2001.

Nacionalna klasifikacija zanimanja 2010. - NKZ 10. // Narodne novine 147, 3736(2010). [citirano: 2021-02-21]. Dostupno na: https://narodne-novine.nn.hr/clanci/sluzbeni/2010_12_147_3736.html.

Obradović, V.; J. Samardžija; J. Jandrić. Menadžment ljudskih potencijala u poslovnoj praksi. Zagreb: Plejada, 2015.

Pastuović, N. Cjeloživotno učenje i promjene u školovanju. // Odgojne znanosti 10, 2(2008), 253-267. [citirano: 2021-02-21]. Dostupno na: https://hrcak.srce.hr/ file/46484.

Petr Balog, K.; S. Faletar Tanacković. Obrazovanje knjižničara i informacijskih stručnjaka u Republici Hrvatskoj s naglaskom na studij informatologije Odsjeka za informacijske znanosti Filozofskog fakulteta Sveučilišta u Osijeku. // 5. stručni skup s međunarodnim sudjelovanjem, Okrugli stol: Prvih dvadeset 21. stoljeća u knjižničarstvu. / uredili M. Kretić Nađ i R. Benić. Beli Manastir: Gradska knjižnica Beli Manastir, 2020. Str. 57-87.

Pojmovnik Hrvatskog klasifikacijskog okvira. [citirano: 2021-02-21]. Dostupno na: https://www.hzz.hr/UserDocsImages/Pojmovnik_Hrvatskoga_kvalifikacijskog okvira.pdf.

Pravilnik o matičnoj djelatnosti i sustavu matičnih knjižnica u Republici Hrvatskoj. // Narodne novine 81, 1506/2021). [citirano: 2021-09-02]. Dostupno na: https://narodne-novine.nn.hr/clanci/sluzbeni/2021_07_81_1506.html.

Pravilnik o uvjetima i načinu stjecana stručnih zvanja u knjižničarskoj struci. // Narodne novine, 107, 1886/2021). [citirano: 2021-010-02]. Dostupno na https://narodne-novine.nn.hr/clanci/sluzbeni/2021_10_107_1886.html.

Pravilnik o uvjetima i načinu stjecana stručnih zvanja u knjižničarskoj struci. Urednički pročišćeni tekst, Narodne novine, 28/11, 16/14, 60/14 - Ispravak i 47/17. [citirano: 2021-02-21]. Dostupno na: http://www.propisi.hr/print.php?id.

Preporuka Vijeća Europske Unije od 22. svibnja 2018. o ključnim kompetencijama za cjeloživotno učenje (2018/C 189/91). [citirano: 2021-02-21]. Dostupno na: https://eur-lex.europa.eu/legal-content/HR/TXT/PDF/?uri=CELEX:32018H0604(01)\&from=BG.

Profesija. // Hrvatska enciklopedija. Mrežno izdanje. Zagreb: Leksikografski zavod Miroslav Krleža, 2021. [citirano: 2020-10-30]. Dostupno na: http://www.enciklopedija.hr/Natuknica.aspx?ID=50537. 
Program Centra za stalno stručno usavršavanje knjižničara u Republici Hrvatskoj u 2021. godini. [citirano: 2021-02-21]. Dostupno na: http://cssu.nsk.hr/wp-content/ uploads/2021/02/PROGRAM-CSSU-A-2021.pdf.

Puhovski, Ž. Prednost demokracije pred znanošću. // Ideje.hr [citirano: 2020-10-30]. Dostupno na: http://ideje.hr/prednost-demokracije-pred-znanoscu.

Radna snaga. // Hrvatska enciklopedija. Mrežno izdanje. Zagreb: Leksikografski zavod Miroslav Krleža, 1999. [citirano: 2020-10-30]. Dostupno na: http://www.enciklopedija.hr/natuknica.aspx?id=51522.

Rubin, R. E. Foundation of library and information science. London: Facet Publishing 2016.

Šverko, B. Ljudski potencijali: Usmjeravanje, odabir i osposobljavanje. Zagreb: Hrvatska sveučilišna naklada, 2012.

Torrington, D.; L. Hall. Personnel management: A New approach. New York: Prentice Hall, 1991.

Villa, A. Organizacija in organiziranje. Kranj: Moderna organizacija, 1994.

Vodič kroz politike i procedure za upravljanje ljudskim potencijalima. Zagreb: Agencija za strukovno obrazovanje i obrazovanje odraslih. [citirano: 2021-02-21]. Dostupno na: https://www.asoo.hr/UserDocsImages/projekti/kapaciteti/Vodic\%20kroz\%20 politike\%20i\%20procedure\%20za\%20upravljanje\%20LJP.pdf.

Vodič kroz sustav obrazovanja u Republici Hrvatskoj. [citirano: 2021-02-21]. Dostupno na: https://mzo.hr/sites/default/files/links/hrvatski_obra zovni_sustav.pdf.

Vujić, V. // Menadžment ljudskog kapitala. Rijeka: Sveučilište, Fakultet za turistički i hotelski menadžment u Opatiji, 2008.

Weihrich, H; H. Koontz. Menadžment. Zagreb: Mate, 1994.

Zakon o knjižnicama i knjižničnoj djelatnosti. // Narodne novine 17, 356(2019). [citirano: 2021-02-21]. Dostupno na: https://narodne-novine.nn.hr/clanci/sluzbeni/2019_02_17_356.html.

Zakon o reguliranim profesijama i priznavanju inozemnih stručnih kvalifikacija: Narodne novine 82/15, 70/19, 47/20, na snazi od 25.04.2020. // Zakon.hr. [citirano: 2020-10-30]. Dostupno na: https://www.zakon.hr/z/499/Zakon-o-reguliranim-profesijama-i-priznavanju-inozemnih-stru\%C $4 \% 8$ Dnih-kvalifikacija. 